\title{
Potential of Complementary and Alternative Medicine in Preventive Management of Novel H1N1 Flu (Swine Flu) Pandemic: Thwarting Potential Disasters in the Bud
}

\author{
Rajesh Arora, ${ }^{1,2}$ R. Chawla, ${ }^{1}$ Rohit Marwah, ${ }^{1}$ P. Arora, ${ }^{3}$ R. K. Sharma, ${ }^{1}$ Vinod Kaushik, ${ }^{1}$ \\ R. Goel, ${ }^{1}$ A. Kaur, ${ }^{3}$ M. Silambarasan, ${ }^{1}$ R. P. Tripathi, ${ }^{1}$ and J. R. Bhardwaj ${ }^{4}$ \\ ${ }^{1}$ Division of Chemical Biological, Radiological and Nuclear (CBRN) Defence, Institute of Nuclear Medicine and Allied Sciences, \\ Defence Research and Development Organization, Brig. S.K. Mazumdar Road, Delhi 110054, India \\ ${ }^{2}$ Department of Chemistry and Biochemistry, Faculty of Medicine, Trakia University, Armeiska Street 1, 6000 Stara Zagora, Bulgaria \\ ${ }^{3}$ Centre for Disaster Management Studies, Guru Gobind Singh Indraprastha University, Kashmere Gate, Delhi 110006, India \\ ${ }^{4}$ Division of Disaster Management, National Disaster Management Authority (NDMA), A1 Safdarjung Enclave, \\ New Delhi 110001, India
}

Correspondence should be addressed to Rajesh Arora, rajesharoradr@rediffmail.com

Received 10 October 2009; Revised 22 April 2010; Accepted 20 August 2010

Copyright (C) 2011 Rajesh Arora et al. This is an open access article distributed under the Creative Commons Attribution License, which permits unrestricted use, distribution, and reproduction in any medium, provided the original work is properly cited.

\begin{abstract}
The emergence of novel H1N1 has posed a situation that warrants urgent global attention. Though antiviral drugs are available in mainstream medicine for treating symptoms of swine flu, currently there is no preventive medicine available. Even when available, they would be in short supply and ineffective in a pandemic situation, for treating the masses worldwide. Besides the development of drug resistance, emergence of mutant strains of the virus, emergence of a more virulent strain, prohibitive costs of available drugs, time lag between vaccine developments, and mass casualties would pose difficult problems. In view of this, complementary and alternative medicine (CAM) offers a plethora of interesting preventive possibilities in patients. Herbs exhibit a diverse array of biological activities and can be effectively harnessed for managing pandemic flu. Potentially active herbs can serve as effective anti influenza agents. The role of CAM for managing novel H1N1 flu and the mode of action of these botanicals is presented here in an evidence-based approach that can be followed to establish their potential use in the management of influenza pandemics. The complementary and alternative medicine approach deliberated in the paper should also be useful in treating the patients with serious influenza in non pandemic situations.
\end{abstract}

\section{Introduction}

Viruses are a serious threat to the health of people in all parts of the world. For most bacterial diseases, several effective drugs are available, however, viral diseases are often difficult to treat primarily because viruses spread and mutate very rapidly. The control and treatment of a viral infection depends mainly on the availability of antiviral drugs, which are few and usually are not virucidal but simply prevent replication in the host. It has become imperative to develop effective medical strategies for the management of common viral diseases like influenza, which can assume pandemic proportions and become a major threat to humanity. Complementary and alternative medicines have been used effectively by humans over several centuries for treating various diseases and can be effectively employed to target the host response during influenza outbreaks [1] and are the focus of the present paper.

\section{Influenza Reassorted Virus: Is a Global Disaster in the Making?}

2.1. Swine Flu: The Current Pandemic. The etymology of the word Pandemic can be traced to a Greek word pandemos "pertaining to all people" and has been derived from pan - "all" + demos - "people". Pandemic is referred to as a pervasive epidemic of contagious disease affecting throughout the whole of a country or one or more continents at the same time. It relates basically to the virus's geographical spread rather than its severity. There have been three flu 


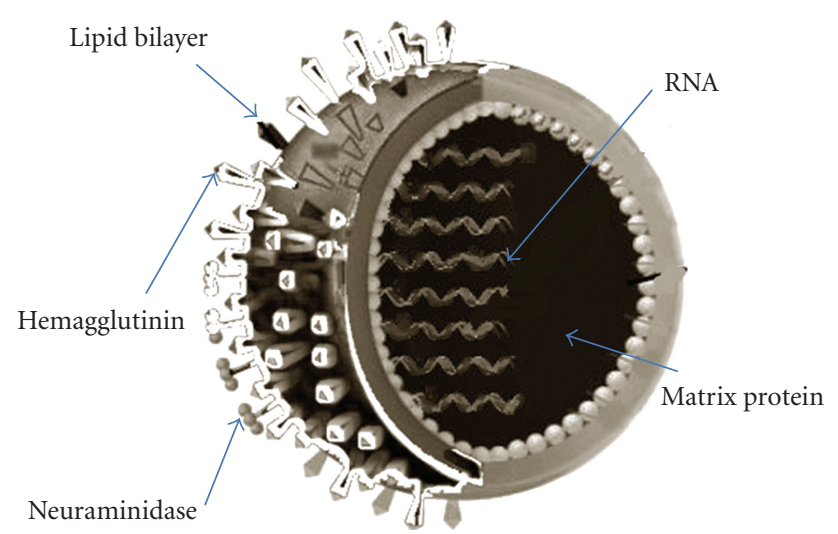

Figure 1: The H1N1 Virus.

pandemics in the 20th century and these occurred in 1918, 1957, and 1968. Influenza A viruses are single-stranded RNA viruses with an eight segmented genome and belong to the family Orthomyxoviridae. The viral haemagglutinin (HA) and neuraminidase (NA) proteins envelope glycoproteins (Figure 1) and are the key antigens against which humoral immune responses are directed.

2.2. Novel H1N1 Flu. Swine flu is a highly contagious respiratory disease of pigs with low mortality $(1 \%-4 \%)$, is species-specific in nature, and outbreak usually occurs once in a year with an upsurge in Autumn and Winter in temperate zones. One such virus, namely, Influenza A H1N1 virus has evolved the capacity to cross species barrier (i.e., pig to humans) and has spread widely amongst humans. This led to a pandemic situation covering nearly the entire globe with a significant pace in terms of spread. More than 213 countries and overseas territories or communities have reported laboratory confirmed cases of pandemic influenza $\mathrm{H} 1 \mathrm{~N} 1$, including at least 16226 deaths. Novel H1N1 flu is characterised with the onset of sudden fever $\left(>38^{\circ} \mathrm{C} / 100.4^{\circ} \mathrm{F}\right)$, cough, tiredness, headache, chills, loss of appetite aching muscles, paining joints, runny nose, sneezing, and sore throat. In case of acute respiratory infections, shortness of breath is one of the additional symptoms. In addition to these mild complications, diarrhoea, and vomiting are also observed in nearly one out of four patients (Figure 2).

2.3. Novel H1N1 Flu: Impact Assessment, Mitigation, and Control Measures. There is a significant variation in number of cases among different regions identified by World Health Organisation (WHO). The number of cases as of now followed the trend American region > European > Western Pacific > South East Asian Region. The followup of H1N1 outbreak in April 2009, reaching Phase V and then VI has exhibited a systematic spread from a single source to global arena. By May 2009, it was established and anticipated that the disease will attain pandemic proportions (Figure 3). The entrance of $\mathrm{H} 1 \mathrm{~N} 1$ virus into the South Asian region with maximal proportion of global population led to a significant increase in number of confirmed cases, with a significant number of global deaths. Till 10 Feb 2010, the number of

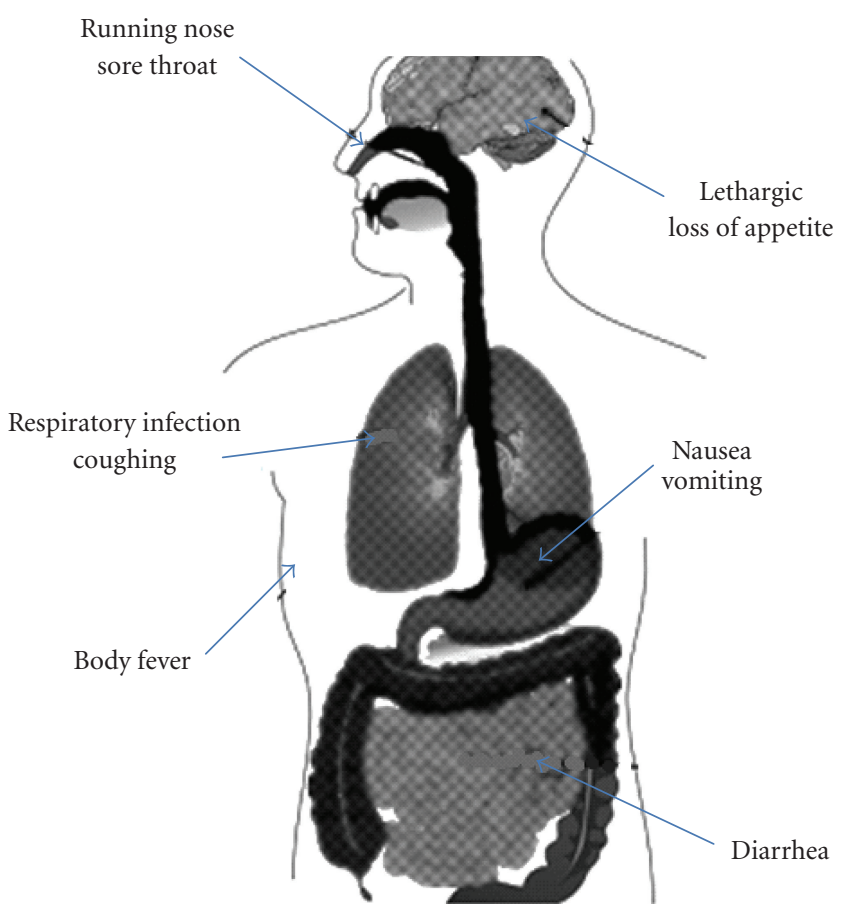

FIgURE 2: Symptoms of Swine flu due to novel H1N1 viral attack.

confirmed human cases of H1N1 in India were 29187 and among these cases, the number of deaths had reached 1278 (Figure 4). The total number of cases has been reported from more than 10 states of the country. A rise in number of cases of H1N1 in the coming months can be expected due to winter approaching. The WHO, however contends that climate does not have any effect.

A report published in May, 2009 revealed that maximal number of confirmed cases was reported in the age group either $<15$ years or 15-29 years, though, more number of deaths occurred in older people [2]. Immunocompromised patients or old people with ageing or preexisting disorders are more vulnerable, and therefore complementary and alternative medicine can be used to boost the natural immune system in a holistic manner. In addition, proper preinfection and postinfection planning can also help in controlling the mortality rate due to Swine flu $[3,4]$.

\section{Modern Therapeutic Interventions: How Safe Are We?}

Modern system of medicine is based on a medical model that basically offers symptomatic treatment and focuses more on therapy. It emphasizes on the use of drugs, mechanical testing, invasive treatments like surgery, and a passive approach towards the patient. In modern medicine, two classes of antiviral medication are currently available for the treatment of seasonal human influenza. Neuraminidase inhibitors like oseltamivir (Tamiflu), zanamivir (Relenza), and adamantanes (rimantadine and amantadine). Interestingly, the starting material for the synthesis of Tamiflu is also a herb (Illicium verum). Genetic and phenotypic 


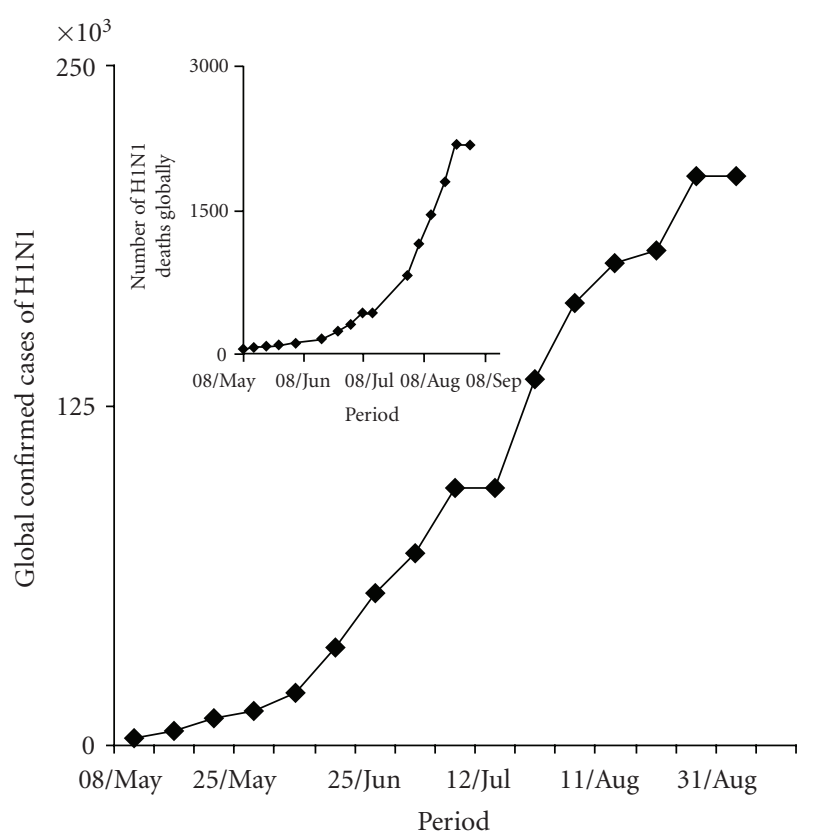

Figure 3: Confirmed cases of H1N1 at global level \& number of deaths (April-Sep 2009).

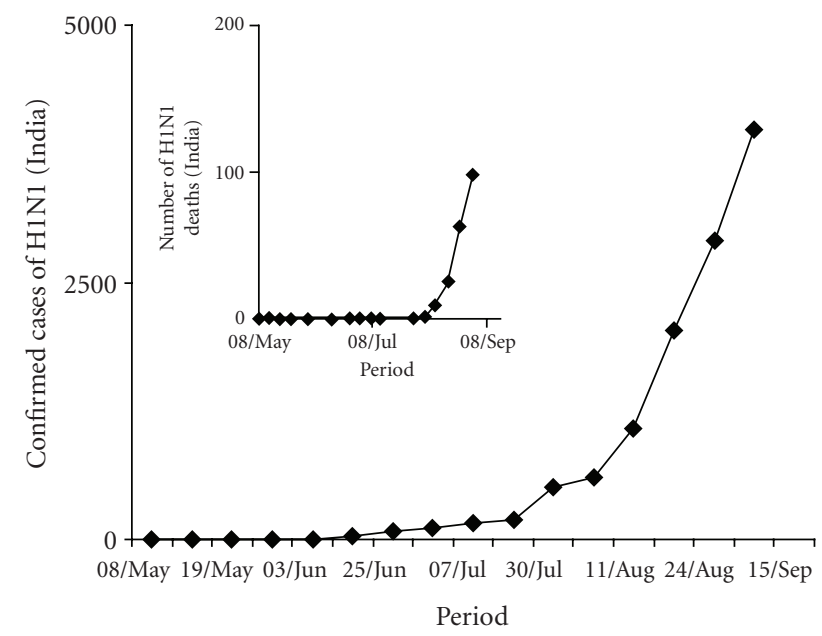

Figure 4: Confirmed cases of H1N1 in India \& number of deaths (April-Sep 2009).

analyses indicate that $\mathrm{H} 1 \mathrm{~N} 1$ is susceptible to oseltamivir and zanamivir, but resistant to the adamantanes. These drugs mainly target three influenza envelope proteins: hemagglutinin, neuraminidase, and the matrix 2 ion channel protein. A recent study emphasized the urgent need for augmentation of oseltamivir (Tamiflu) stockpiles with additional antiviral drugs, including Zanamivir (Relenza), based on an evaluation of the performance of these drugs in the scenario that the $2009 \mathrm{H} 1 \mathrm{N1}$ "Swine Flu" neuraminidase (NA) were to acquire the Tamiflu-resistance (His274Tyr) mutation, which is currently wide-spread in seasonal H1N1 strains [5]. Treatment with amantadines may lead to the

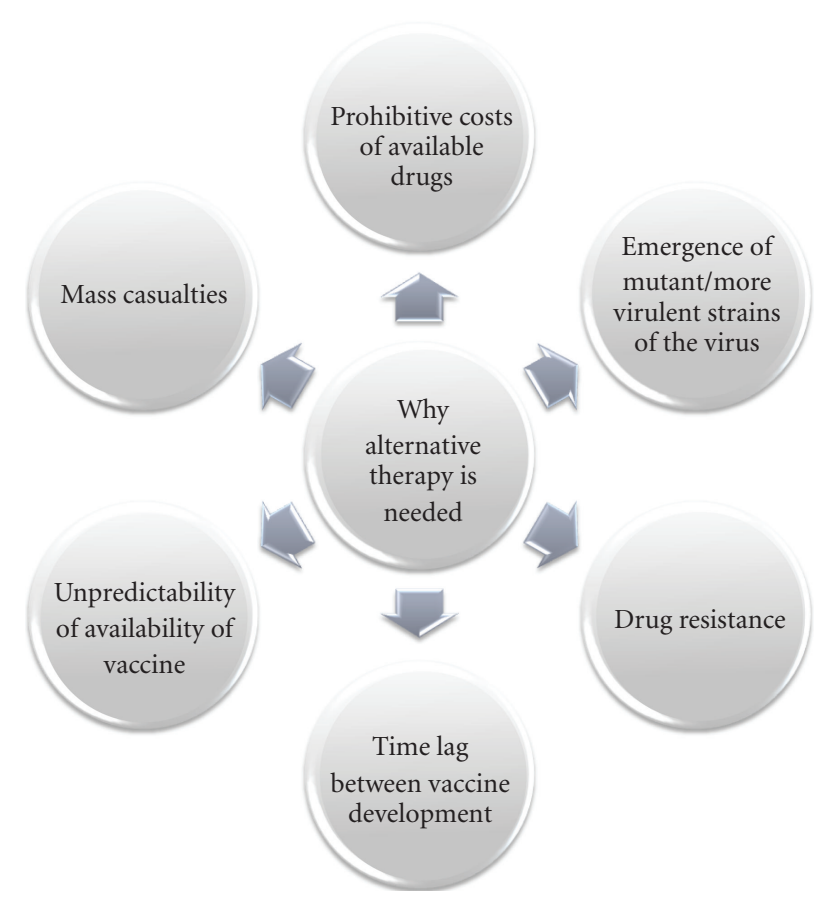

FIGURE 5: Need for an alternative therapy to manage novel H1N1 viral infection.

rapid production of resistant viruses, and over-use of these drugs has probably contributed to the recent spread of resistance [6]. Laboratory studies have also shown that it is possible that even the use of suboptimal doses of these drugs as a prophylactic measure might contribute to the development of drug resistance [7].

\section{Why Alternatives Are Needed?}

The need for alternatives arises because of some of the following reasons (Figure 5).

\section{Solutions from Nature}

5.1. Learning from Traditional Wisdom. Complementary and alternative medicine has been utilized for several years in various parts of the world to alleviate human disease. The preventive role of complementary and alternative medicine, in particular, cannot be overemphasized. "Complementary" implies that it joins conventional medicine as an equal counterpart to make the healing process complete. Alternative medicine substitutes for conventional medicine. It neither works with nor enhances conventional medicine, but rather acts as its replacement. Complementary and alternative medicine has been used for the well-being of the general population, especially when conventional modern medicine has failed to deliver and has also been used at times in conjunction with conventional medicine to obtain synergistic effects.

The traditional Indian System of Medicine, namely, Ayurveda [8], Traditional Chinese medicine (TCM) $[8,9]$, 
Japanese traditional medicine (Kampo) [10], Unani [11], Siddha, and so forth, belong to the category of complementary and alternative medicines. For some or the other reason the alternative herbal treatment systems have so far been unable to enter mainstream medicine [12], though serious efforts are being made, in view of their effectiveness, to develop a strong evidence-based standardization of Ayurveda, Siddha, Unani, Traditional Chinese Medical Therapy [13], and other CAM so that they can aptly fit into the modern medicinal framework.

Ayurveda, the traditional Indian system of medicine, has been widely used since centuries and a number of plants of the Indian subcontinent have been utilized for tackling almost every human ailment. Ayurveda's focus is more on creating an energetic balance at the higher energetic or inner level. It sees all life and nature as constantly evolving towards a higher level of consciousness [14]. Ayurvedic formulations have an impact at this higher level of consciousness, as well as the more gross body level. Ayurveda seeks to connect us with this intelligence inherent in nature. These profound concepts, based upon an astute understanding of the universal laws and practical observations about the world around, give us the indication about the holistic approach of Ayurveda and its potential in alleviating many health-related problems afflicting the whole of humanity. Several antiviral agents have been isolated from plants as a result of chemical and pharmacological studies in the recent years, and many have been derived from leads based on Ayurvedic and other traditional medicine principles. These agents include a variety of polyphenols, flavonoids, saponins, glucosides, and alkaloids [15]. Here, we discuss various potential herbs that have been evaluated for their efficacy against flu viruses and hence can prove to be useful to combat the novel H1N1 pandemic.

5.1.1. Glycyrrhiza glabra. Also known as Yashtimadhu (Sanskrit), Mulathee (Hindi), and Licorice (English), Glycyrrhiza glabra (Papilionaceae) derives its flavour principally from a sweet-tasting compound called anethole ("trans"-1methoxy-4-(prop-1-enyl)benzene). Additional sweetness in licorice comes from glycyrrhizic acid, an antiviral compound significantly sweeter than sugar [16]. Powdered licorice root is an effective expectorant, and has been used for this purpose since ancient times, especially in Ayurvedic medicine. The roots of the plant have been used for throat and upper respiratory tract-related infections and contain many phenolic compounds such as flavonoids and their glycosides, coumarin, and cinnamic acid derivatives. Particularly from the Indian species, Glucosides, Liquiritin, and Isoliquiritin have also been isolated. The active compounds Triterpine, Saponins, particularly Glycyrrhizinic acid have shown antiviral activity [17]. Polysaccharide fractions obtained from Glycyrrhiza glabra stimulate macrophages [18] and hence elevate and assist immune stimulation [19]. Also animal studies have revealed its efficacy against the influenza a virus that is mediated by stopping the virus replication [20]. Glycyrrhizic acid present in the plant inhibits virus growth and inactivates virus particles [21].
5.1.2. Ocimum sanctum. O. sanctum, also known as Tulsi (Hindi) and Holy Basil (English), is an aromatic plant of the family Lamiaceae. The plant, as a whole, is a treasure house of potent compounds with its leaves, seeds, and roots, as well as flower being medicinally important and is considered divine by the Hindus. O. sanctum is considered to be an adaptogen par excellence $[22,23]$. It harmonizes different processes in the body and is helpful in acclimatizing to stress. The main chemical constituents of $O$. sanctum are oleanolic acid, ursolic acid, rosmarinic acid, eugenol, carvacrol, linalool, and $\beta$-caryophyllene [23]. The antiviral activity of eugenol has been reported. Ocimum extracts are used in ayurvedic remedies for common colds, headaches, stomach disorders, inflammation, heart disease, various forms of poisoning, and malaria. Traditionally, O. sanctum is taken in many forms as herbal tea, dried powder, fresh leaf, or mixed with ghee. Essential oil extracted from Karpoora O. sanctum is mostly used for medicinal purposes and in herbal cosmetics, and is widely used in skin preparations due to its antimicrobial activity [24]. Recent studies suggest that O. sanctum may be a COX-2 inhibitor, like many modern painkillers, due to its high concentration of eugenol (1-hydroxy-2-methoxy-4allylbenzene) [25]. O. sanctum is reported to be an effective treatment for diabetes and high cholesterol [26]. O. sanctum also shows promise for protection against radiation damage $[27,28]$. O. sanctum leaves contain highest percentage of essential oils, infusion of which is given in malaria. Juice of the leaves is taken internally and is very effective in skin diseases such as itches fungal infections. Fresh leaves also cure chronic fever and when mixed with honey and ginger juice, it is useful in cough and bronchitis [29]. During the past decade the plant has been extensively investigated and has been shown to possess a range of biological activities such as antibacterial activity [30], antifungal activity [31], and antiviral activity [32]. Nitric oxide production was induced by $O$. tenuiflorum extracts in stimulated peripheral blood mononuclear cells in vitro and the active component(s) responsible for immunomodulatory action were identified [33]. The extract was also used to stimulate the cells individually and in combination with mitogens as well [34]. The antimicrobial properties of $O$. sanctum make it useful for the management of novel H1N1 flu.

5.1.3. Alium sativum. Alium sativum, also known as Lahsan (Hindi) and Garlic (English), belongs to family Alliaceae. A. sativum has been used throughout recorded chronicles for both culinary and medicinal purposes. It has a characteristic pungent, spicy flavor. A. sativum has been used for hundreds of years to treat fungal, parasitic, and viral infections, and has anti-inflammatory properties that show promise for prevention of cardiovascular disease. It is known to kill influenza virus in vitro [35]. Researchers are focusing on an extract of $A$. sativum called ajoene, which appears to protect CD + cells from attack by HIV early in the viral life cycle. At low concentrations, the drug appears to have little toxicity, and its anti-HIV activity is 45 times more powerful than the drug dextran sulfate. Ajoene is found only in fresh $A$. sativum and is not readily procurable. Recent investigations reveal that $A$. sativum impairs the activity of the liver 
enzymes that process protease inhibitors and raises the protease inhibitor levels. The in vitro antiviral activity of $A$. sativum extract (GE) on human cytomegalovirus (HCMV) was also evaluated in tissue cultures, plaque reduction, and early antigen assay. A dose-dependent inhibitory effect of GE was evident when GE was applied simultaneously with HCMV [36]. The in vitro antiviral effect of garlic against parainfluenza virus type 3 and human Rhinovirus type 2 has also been evaluated [37].

5.1.4. Cocos nucifera. The coconut (Cocos nucifera) belongs to the Family Arecaceae (palm family). The most common form of its usage is the coconut oil, which is extracted from the kernel of matured coconut (Cocos nucifera). Throughout the tropical regions, it has been the primary source of fat in the diets of millions of people since aeons. Cocos nucifera oil has a long history of use, both as food and as medicine, throughout the world. It holds a high place of respect in Ayurvedic medicine in India. In folk remedies around the world, coconut is used to treat a wide assortment of ailments including abscesses, alopecia, amenorrhea, asthma, blenorrhagia, bronchitis, bruises, burns, cachexia, calculus, colds, constipation, cough, debility, dropsy, dysentery, dysmenorrhea, earache, erysipelas, fever, flu, gingivitis, gonorrhea, hematemesis, hemoptysis, jaundice, menorrhagia, nausea, phthisis, pregnancy, rash, scabies, scurvy, sore throat, stomachache, swelling, syphilis, toothache, tuberculosis, tumors, typhoid, venereal diseases, and wounds [20]. It has been reported that certain fatty acids, primarily medium-chain fatty acids (MCFA), and their derivatives (e.g., monoglycerides) have potent antiviral properties [59]. When C. nucifera oil is consumed, the mediumchain triglycerides (MCTs) are broken down into individual medium chain fatty acids and monoglycerides, which can kill or inactivate pathogenic microorganisms inside the body. The antiviral action, attributed to monolaurin (the monoglyceride of lauric acid), is that of solubilizing the lipids and phospholipids in the envelope of the pathogenic organisms causing the disintegration of their outer membrane. There is also evidence that MCFA interfere with the organism's signal transduction [60] and the antimicrobial effect in viruses is due to interference with virus assembly and viral maturation [61].

5.1.5. Zingiber officinale. Zingiber officinale (Ginger) is a plant which belongs to the family Zingiberaceae. The characteristic odor and flavor of ginger root is caused by a mixture of zingerone, shogaols, and gingerols, volatile oils that comprise of about one to three percent of the weight of fresh ginger. In laboratory animals, the gingerols increase the motility of the gastrointestinal tract and have analgesic, sedative, antipyretic, and antibacterial properties [62]. Ginger contains gingerol, a pungent ingredient of ginger volatile oil with sulphur-containing compounds (allicin, alliin, and ajoene), and enzymes (allinase, peroxidase, and myrosinase). The antibiotic properties of allicin are well known. The allicins have fibrinolytic activity, which reduces platelet aggregation by inhibiting prostaglandin E2. Compounds in ginger also increase levels of antioxidant enzymes, including superoxide dismutase and glutathione peroxidase, which may be beneficial in inflammatory reactions triggered by viral infections [63]. Anti-influenza agents have been isolated from $Z$. officinale. TNF- $\alpha$, reported as anti-influenza cytokine, has been reported to be present in ginger [64].

5.1.6. Phyllanthus emblica. The Indian gooseberry (Phyllanthus emblica, syn. Emblica officinalis) is a deciduous tree of the Euphorbiaceae family. It is also known as Amlaka (sanskrit) and Amla (Hindi). In traditional Indian medicine, dried and fresh fruits of the plant are used. All parts of the plant, including the fruit, seed, leaves, root, bark, and flowers, are used in various Ayurvedic/Unani Medicine herbal preparations. According to Ayurveda, Emblica officinalis fruit is sour and astringent in taste, with sweet, bitter, and pungent secondary tastes.

Methanol extract of the fruit of Emblica officinalis has potent inhibitory action against human immunodeficiency virus-1 reverse transcriptase. Emblica officinalis aqueous extracts are used in Cuban traditional medicine for their antiviral activity against Hepatitis $\mathrm{B}$ virus and $\mathrm{A}$ and $\mathrm{B}$ influenza virus. The cytotoxicity of the extract was tested by means of colony-forming ability and growth-inhibition assays, as well as by measuring the mitotic index. Apoptosis induction and cell-cycle kinetics were analyzed by cytofluorimetric methods [72]. In Ayurvedic polyherbal formulations, Emblica officinalis is a common constituent, and most notably is the primary ingredient in an ancient herbal preparation called Chyawanprash [73], which is itself an effective adaptogen and immunity booster that could help control swine flu infection.

5.1.7. Tinospora cordifolia. Tinospora cordifolia, also called Guduchi, is a herbaceous vine of the family Menispermaceae indigenous to the tropical areas of India, Myanmar, and Sri Lanka. The active constituents are diterpene compounds, including tinosporone, tinosporic acid, cordifolisides A to E, syringen, the yellow alkaloid, berberine, Giloin, crude Giloininand, and a glucosidal bitter principle, as well as polysaccharides, including arabinogalactan polysaccharide (TSP) $[74,75]$. These compounds possess adaptogenic and immunomodulating properties. Picrotene and bergenin, possessing antioxidant properties have been reported from Tinospora. Tinospora cordifolia has been studied extensively for its immunomodulating activities. The active principles of Tinospora cordifolia were found to possess immunomodulatory activities and caused significant increases in IgG antibodies in serum, along with macrophage activation [76]. Enhancement in humoral immunity, evidenced by the hemagglutination titre, along with stimulation of cellmediated immunity were observed in the leukocyte migration inhibition tests [77]. The plant has immense potential for use against novel H1N1 flu since it is a potent immunostimulant.

5.1.8. Mentha piperita. Mentha piperita, family Labiatae, is a herbaceous rhizomatous perennial plant widely used in Ayurveda [78]. It contains about 1.2\%-1.5\% essential oil. The volatile oil, also known as menthae piperitae 
aetheroleum, contains 30-70\% free menthol, menthol esters and more than 40 other compounds. The principal components of the oil are menthol (29\%), menthone $(20 \%-$ $30 \%)$, and menthyl acetate (3\%-10\%). Pharmaceutical grade oil, produced by distilling the fresh aerial parts of the plant at the beginning of the flowering cycle, is standardized to contain no less than $44 \%$ menthol, $15 \%$ $30 \%$ menthone, and $5 \%$ esters, in addition to various terpenoids. Other compounds found in it are flavonoids (12\%), polymerized polyphenols $(19 \%)$, carotenes, tocopherols, betaine, and choline [79]. The antimicrobial and antiviral activity of menthol has been reported. Mentha piperita has significant antiviral activity [80]. Menthol is virucidal against influenza, herpes, and other viruses in vitro. Aqueous extracts of peppermint leaves exhibited antiviral activity against Influenza A, Newcastle disease virus, Herpes simplex virus, and Vaccinia virus in egg and cell-culture systems [81]. The oil contains terpenoids such as $\alpha$-pinene or $\beta$-pinene, $\alpha$-phellandren, and also ester-connected with menthol or free acetic acid and isovaleric acid, which are mainly responsible for the antimicrobial activity of the herb [82].

5.1.9. Azadirachta indica. Azadirachta indica (Neem in Hindi) is a tree in the mahogany family Meliaceae. Three bitter compounds that have been extracted from neem oil are nimbin, nimbinin, and nimbidin, respectively [83]. The seeds contain a complex secondary metabolite azadirachtin. All parts of the plant yield $\beta$-sitosterol. The antiviral activity of azadirachtin, nimbin, and nimbidin has been reported. Azadirachta indica extracts possess antidiabetic, antibacterial, and antiviral properties. The tree stem, root, and bark possess astringent and tonic properties [84, 85]. In vitro antiviral activity of aqueous neem leaves extract, assessed in cloned cells of larvae of Aedes albopictus cells employing virus inhibition assay, showed inhibition in a dose-dependent manner [86].

Azadirachta indica has traditionally been used as an antiviral, and animal and laboratory research has shown promising results. While researchers have still not pinpointed the exact mode of action of neem phytoconstituents, there is some evidence to show that they interfere with viral reproduction, thus minimizing the impact of viral infections. The effect of $A$. indica leaf extract and pure compound (Azadirachtin) on the replication of Dengue virus type- 2 has also been reported. Thus, neem can serve as a source of promising future antiviral drugs [85].

5.1.10. Aegle marmelos. Aegle marmelos also called Bael (Hindi) belongs to family Rutaceae. It contains primarily alkaloids, coumarins, and steroids. The leaves contain skimianinc, sterol, and aegelin. The active constituent of the fruit is marmorosin, which is identical to imperatorin. Coumarins contained in the fruits are altoimperatorin and $\beta$ sitosterol. Roots of the tree have been found to contain psoralin, xanthotoxin, scopoletin, and tebamide. $A$. marmelos from India is reported to possess imperetorin [87], which has certain interesting biological properties such as analgesic, anti-inflammatory, antibacterial, and antiviral properties.

All parts of this tree-stem, bark, root, leaves, and fruit at all stages of maturity have been used in Ayurveda since ages. Medicated oil prepared from bael leaves gives relief from recurrent colds and respiratory infections. Its regular use builds up resistance to colds and coughs. The unripe fruit possesses significant antiviral activity.

5.1.11. Trachyspermum ammi. Trachyspermum ammi, called as Ajwain in Hindi and Bishops weed in English, is a member of the family Apiaceae. The principal constituents of the essential oil from the fruit are the phenols, mainly thymol and some carvacrol. The oil possesses $\mathrm{p}$-cymene, g-terpinene, $\alpha$ - and $\beta$-pinenes, and dipentene, minute amounts of camphene, myrcene, and carene [88]. The essential oil is a strong antiseptic [89], antispasmodic, aromatic, bitter, diaphoretic, digestive, diuretic, expectorant, and tonic [90]. It is used internally in the treatment of colds, coughs, influenza, and asthma. The essential oil is also added to various cough medicines as well [89].

\subsubsection{Andrographis paniculata. Andrographis paniculata} (Kalmegha in Hindi) is a herbaceous plant in the family Acanthaceae, native to India and Sri Lanka. It is sometimes called "Indian Echinacea" because it is believed to provide much the same benefits as Echinacea. Andrographolide, the major constituent of the extract is implicated towards its pharmacological activity. Studies have been conducted on the cellular processes and targets modulated by andrographolide treatment of immune cells. Andrographis was found to both reduce the symptoms and shorten the duration of colds in clinical trials [90]. Andrographis paniculata also reduced the cold symptoms such as fatigue, sore throat, sore muscles, runny nose, headache, and lymph node swelling [91]. Unlike the Echinacea, Andrographis does not have any side effects.

5.1.13. Terminalia chebula Retz. Terminalia chebula, is a deciduous tree of family Combretaceae native to Southern Asia from India and Nepal east to Southwestern China (Yunnan), and south to Sri Lanka, Malaysia, and Vietnam. It is regarded as a universal panacea. The dry nut's peel from this plant is used to cure cold-related nagging coughs. The bark/peel of the nut is placed in the cheek and this generates a huge amount of saliva as the material does not dissolve. The resulting saliva, bitter in taste, is believed to have medicinal qualities to cure cold related coughs. Its fruits possess digestive, anti-inflammatory, anthelmentic, cardiotonic, aphrodisiac, and restorative properties and are additionally beneficial in cough and colds. Terminalia chebula is an important medicine, which often promotes health through successive steps of purification and detoxification. It is known to have strong antimutagenic activity, because of its very rich content vitamin $C$ [92]. Also it is an established potent free radical scavenger [93]. 


\section{Traditional Chinese Medicine}

Some plants that are extensively used in Traditional Chinese Medicine and could prove useful for the management of swine flu are as follows.

6.1. Sophora flavescens. Sophora flavescens is a species of plant in the genus Sophora. Its roots are regionally called ku shen or kushenin [94] which is the source of flavonoids and is used as traditional Chinese medicine [95]. Its roots also contain quinolizidine alkaloids, including matrine and its oxide [96], that interfere TNF-alpha and IL-6, suggesting that oxymatrine may inhibit the expression of the above proinflammatory cytokines [97]. Recent studies have shown that the plant also contains 8-Prenylkaempferol (8-PK), a prenylflavonoid in its roots. The principle bioactive constituents of $S$. flavescens are the major quinolizidine alkaloids matrine (MT) and oxymatrine (OMT), which were reported to exhibit sedative, depressant, antitumor, antipyretic, and cardiotonic activities.

Due to its antiviral action, the plant has been the focus of attention for innovative studies. The recent studies to appraise its efficacy against H1N1 infection have yielded positive outcomes. Cell inoculation with $\mathrm{H} 1 \mathrm{~N} 1$ evoked a significant induction in RANTES accumulation accompanied with time-related increase in nuclear translocation of nuclear factor- $\kappa \mathrm{B}(\mathrm{NF}-\kappa \mathrm{B})$ and interferon regulatory factor 3 (IRF3 ), but showed no effect on c-Jun phosphorylation. 8-P $\kappa$ could significantly inhibit not only RANTES production, but also NF-kappaB and IRF-3 nuclear translocation [98].

6.2. Toddalia asiatica. Toddalia asiatica (Lopez root) belongs to family Rutaceae, a woody liana, found in mainly Philippines and southern China. It is a large, spiny, woody vine, which is pungent in all its parts and possesses sharp recurved prickles. The leaves are trifoliolate. The leaflets are stalkless, ovate-elliptic, 3 to 8 centimeters long, 5 to 15 millimeters wide, rounded at the base, and pointed at the apex. The flowers are small, greenish-white, 5 millimeters across, and borne on terminal cymes or from the upper leaf axils. The fruit is small, nearly spherical, less than 1 centimeter in diameter, borne in fairly large clusters, 3 to 5 grooved, and with as many cells, and orange red when ripe. The seed is solitary in each cell. T. asiatica is used traditionally in the treatment of malaria, sprains, cough, fever, neuralgia, epilepsy, dyspepsia, and other disease conditions. Extracts of the plant have been reported to have anticancer, antimicrobial, antiviral (anti-HIV), and antifeedant activities. A wide range of chemical constituents such as benzophenanthridine alkaloids, coumarins, cyclohexylamides, and terpenoids have been isolated especially from the root bark of the plant [99]. The essential oil from the plant is a highly potent antimicrobial agent $[100,101]$.

6.3. Schefflera heptaphylla, Chinese Herbal Tea. Schefflera heptaphylla belongs to the family Scarabaeoidea. Leaves are palmately compound, rarely unifoliolate (not in China); margins entire to serrate; stipules united within petiole. Inflorescence is a terminal or pseudolateral panicle or compound raceme; flowers arranged in umbels, heads, or racemes; bracts pubescent, deciduous, or persistent. Pedicels are not articulate below ovary. Calyx rim is entire or 5toothed. Petals are arranged 5-1, $\mathrm{d}$ are valvate. It is a critically endangered species. It is polyphyletic [102-104].

* Frodin is the principal ingredient of a herbal tea formulation that is widely used for the treatment of common cold in Southern China. An extract of the long leafstalk of the compound leaf of S. heptaphylla exhibited the most potent antiviral activity against respiratory syncytial virus. Triterpenoids, namely, 3alpha-hydroxylup20[29]-ene-23,28-dioic acid and 3-epi-betulinic acid 3-O-sulfate, together with an inactive saponin, 3alphahydroxylup-20(29)-ene-23,28-dioic acid 28-O-alpha-1rhamnopyranosyl-(1-->4)-O-beta-d-glucopyranosyl-(1-->6)beta-d-glucopyranoside are present in the plant [105]. Three caffeoylquinic acid derivatives, namely 3,4-di-Ocaffeoylquinic acid, 3,5-di-O-caffeoylquinic acid, and 3-O-caffeoylquinic acid, were also isolated from this plant. These compounds were tested for their activity against Respiratory Syncytial virus. Studies revealed that they exerted their anti-RSV effects via the inhibition of virus-cell fusion in the early stage, and the inhibition of cell-cell fusion at the end of the RSV replication cycle [106].

6.4. Camellia sinensis or Green Tea. Green tea is a type of tea made solely from the leaves of Camellia sinensis that has undergone minimal oxidation during processing. Green tea originated in China and has now become associated with many cultures in Asia from Japan to the Middle East. Recently, it has become more widespread in the West, where black tea is traditionally consumed.

Green tea is particularly rich in polyphenolic compounds and catechins. Catechin derivatives have shown pronounced antiviral activity, observed for derivatives carrying moderate chain length (7-9 carbons). The derivatives exerted inhibitory effects for all six influenza subtypes tested including three major types of currently circulating human influenza viruses (A/H1N1, A/H3N2, and B type), H2N2 and $\mathrm{H} 9 \mathrm{~N} 2$ avian influenza virus. The compounds strongly inhibited adsorption of the viruses on red blood cell (RBC) [107].

The disease preventive properties of green tea are mainly due to the presence of polyphenols like epigallocatechin3-gallate (EGCG), epicatechin, epicatechin-3-gallate, and epigallocatechin (EGC). These polyphenols comprise about one-third of the weight of the dried leaf of the plant. These catechins have been reported to possess diverse pharmacological properties, including antioxidative, antiinflammatory, anticarcinogenic, antimutagenic and antimicrobial effects. Green tea has the ability to enhance humoral and cell-mediated immunity and is, therefore, useful for preventing influenza by inhibiting flu replication, using potentially direct virucidal effect [108].

6.5. Panax quinquefolius. Panax quinquefolius, commonly known as American Ginseng, is an herbaceous perennial in the ivy family that is commonly used in medicine. It is native to Eastern North America, though it also cultivated beyond 




FIGURE 6: The mechanism of action of some isolated compounds from herbs and their role in prevention and treatment of novel H1N1 flu.

its range in places such as China [109]. American ginseng contains dammarane-type ginsenosides as the major biologically active constituents. Dammarane type ginsenosides include two classifications: the 20(S)-protopanaxadiol (ppd) and 20(S)-protopanaxatriol (ppt) classifications. American ginseng contains high levels of Rb1, Rd (ppd classification), and $\mathrm{Re}$ (ppt classification) ginsenosides that are helpful in prevention of common cold [110]. In Eastern Europe, ginseng is widely used to improve overall immunity to illness. It appears that regular use of ginseng may prevent colds. Studies have been done on Panax to reveal that they effectively provide immunity to individuals against influenza [111].

6.6. Echinacea. Echinacea is a genus of nine species of herbaceous plants in the family Asteraceae. It is purely native to North America. The principal effect of these species is to stimulate the body immune system. It appears to activate the body's infection-fighting capacity, which is primarily due to the presence of various chemical compounds such as polysaccharides, phenols, alkylamides, and Cichoric acid. Studies in Europe have concluded that Echinacea, when taken at first sign of cold, reduced cold symptoms or shortened their duration [112]. There is some evidence that, when taken at the onset of a cold or flu, Echinacea can help patients recover faster and reduce their symptoms while they are sick. For example, Echinacea significantly reduced symptoms such as headache, lethargy, cough, and aching limbs $[113,114]$ when administered to people with flu-like illnesses. The constituents found in Echinacea were found to increase antibody production, raise white blood cell counts, and stimulate the activity of key white blood cells [115-118].

Some of the studies have also reported about the allergic effects of Echinacea. Echinacea should not be taken by persons with progressive systemic and autoimmune disorders, connective tissue disorders, or related diseases. It should not be used with immunosuppressants or hepatotoxic drugs, [119] and has the potential to interfere with anesthesia.

\section{CAM for the Management of H1N1: The Way Ahead}

From the foregoing account it is apparent that several medicinal plants have the potential to be used effectively for the management of H1N1. These medicinal herbs mainly act via two basic approaches against H1N1 infection, namely, 


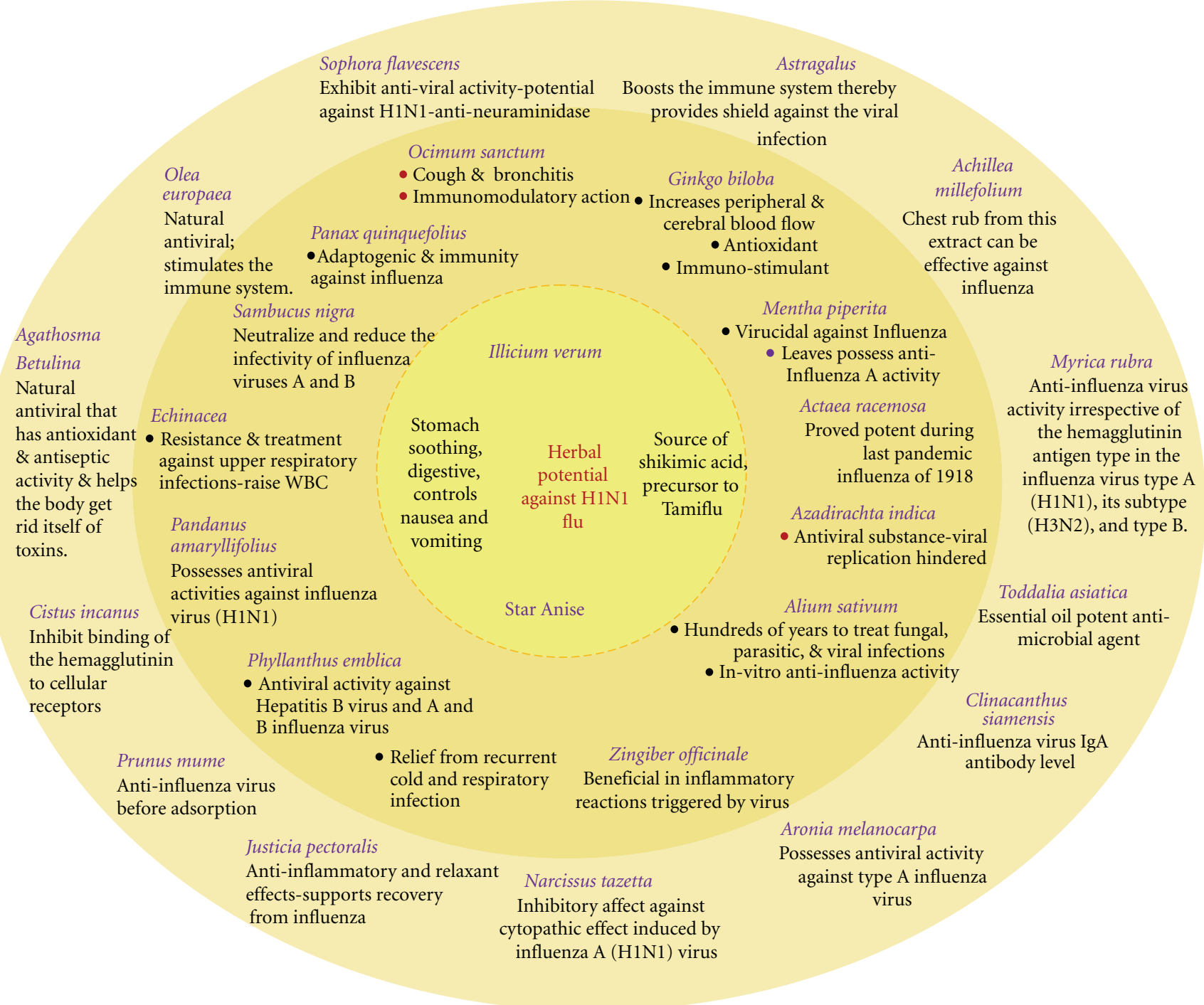

FIGURE 7: Medicinal plants present a plethora of options for the prevention and treatment of novel H1N1 in view of their multifarious modes of action.

enhancement of overall immunity of the individual or by acting against the virus by preventing viral replication or by inhibiting viral signal transduction. Table 1 enumerates the various medicinal herbs from all over the globe that have been found to be potent against the virus, while Figure 6 aptly depicts that genetic modifications have led to the evolution of the deadly $\mathrm{H} 1 \mathrm{~N} 1$ virus and discusses the mechanistic aspects vis-a-vis isolated phytomolecules. The herbs that boost the overall immunity of the body by stimulating specific or nonspecific entities of the immune system, thereby improving the individual's ability to tackle infections, have been listed in Table 2 .

Antiviral agents have been isolated from plants as a result of a recent resurgence of chemical and pharmacological studies. These agents include a variety of polyphenols, flavonoids, saponins, glucosides, and alkaloids [15]. Such isolated compounds may prove to be highly beneficial in controlling the mortality/morbidity rate resulting due to $\mathrm{H} 1 \mathrm{~N} 1$ swine flu since they target various pathways and act at multifarious levels. The mechanisms by which some of the potent bioactive compounds act have been elucidated to some extent. For example kaempferol, isolated from Emblica officinalis, acts via solubilisation of viral outer lipoprotein [72]; azadirachtin, isolated from Azadirachta indica, hinders the viral transduction [86]; glycyrrhizic acid from Glycyrrhiza glabra [17] and ginkgolides from Ginkgo biloba increase virus-specific antibodies in the infected individual. Zingerone and gingerols from Zingiber officinalis prevent viral replication and also intervene in the process of virushost fusion [63].

The need of the hour is not only to isolate and characterize compounds from the various medicinal plants but to utilize medium, high and ultrahigh-throughput methods of screening, molecular profiling, which will involve 
TABLE 1: List of medicinal plants from all over the world, which may prove useful to combat Swine flu.

\begin{tabular}{|c|c|c|c|c|c|c|}
\hline S. no. & $\begin{array}{l}\text { Plant and its } \\
\text { origin }\end{array}$ & Native & Family & $\begin{array}{l}\text { Principal chemical } \\
\text { compounds }\end{array}$ & Anti-influenza action & Reference \\
\hline 1 & $\begin{array}{l}\text { Clinacanthus } \\
\text { siamensis }\end{array}$ & Thailand & Acanthaceae & $\begin{array}{l}\text { Trans-3-methylsulfonyl- } \\
\text { 2-propenol, } \\
\text { trans-3-methylsulfinyl- } \\
\text { 2-propenol }\end{array}$ & $\begin{array}{l}\text { Significant production of anti-influenza } \\
\text { virus IgG(1) antibody produced a higher } \\
\text { anti-influenza virus IgA antibody level. }\end{array}$ & {$[38]$} \\
\hline 2 & Myrica rubra & Japan & Myricaceae & $\begin{array}{l}\text { Phenolic compounds, } \\
\text { chlorogenic acid, } \\
\text { Catechol, Gallic acid }\end{array}$ & $\begin{array}{l}\text { Anti-influenza virus activity irrespective } \\
\text { of the hemagglutinin antigen type in the } \\
\text { influenza virus type A (H1N1), its } \\
\text { subtype (H3N2), and type B. }\end{array}$ & [39] \\
\hline 3 & Narcissus tazetta & China & Amaryllidaceae & A fetuin-binding peptide & $\begin{array}{l}\text { Significantly inhibit the plaque formation } \\
\text { by respiratory syncytial virus (RSV) and } \\
\text { the cytopathic effect induced by influenza } \\
\text { A (H1N1) virus. }\end{array}$ & {$[40]$} \\
\hline 4 & Prunus mume & Japan & Rosaceae & $\begin{array}{l}\text { Presence of a lectin-like } \\
\text { molecule }\end{array}$ & $\begin{array}{l}\text { Strong in vitro anti-influenza activity } \\
\text { against human influenza A viruses before } \\
\text { viral adsorption. }\end{array}$ & {$[41]$} \\
\hline 5 & Cistus incanus & Mediterranean & Cistaceae & $\begin{array}{l}\text { Polymeric polyphenol } \\
\text { components }\end{array}$ & $\begin{array}{l}\text { Inhibit binding of the hemagglutinin to } \\
\text { cellular receptors thereby, a local } \\
\text { application of the extract at the viral } \\
\text { entry routes may be a promising } \\
\text { approach and thus help to provide } \\
\text { protection from influenza virus } \\
\text { infections. }\end{array}$ & {$[42]$} \\
\hline 6 & $\begin{array}{l}\text { Pandanus } \\
\text { amaryllifolius }\end{array}$ & $\begin{array}{l}\text { Malaysia, } \\
\text { Indonesia }\end{array}$ & Pandanaceae & A Lectin called Pandanin & $\begin{array}{l}\text { Possesses antiviral activities against } \\
\text { influenza virus (H1N1). }\end{array}$ & {$[43]$} \\
\hline 8 & $\begin{array}{l}\text { Sophora } \\
\text { flavescens }\end{array}$ & Korea & Leguminosae & $\begin{array}{l}\text { Pterocarpans and } \\
\text { flavanones }\end{array}$ & $\begin{array}{l}\text { Ability to inhibit neuraminidase an } \\
\text { enzyme identified as crucial for the } \\
\text { proliferation of the influenza virus. }\end{array}$ & {$[44]$} \\
\hline 9 & $\begin{array}{l}\text { Aronia } \\
\text { melanocarpa }\end{array}$ & North America & Rosaceae & $\begin{array}{l}\text { Phenolic substances } \\
\text { anthocyanins, glycosides }\end{array}$ & $\begin{array}{l}\text { Antiviral activity against type A influenza } \\
\text { virus. }\end{array}$ & {$[45]$} \\
\hline 10 & $\begin{array}{l}\text { Schefflera } \\
\text { heptaphylla }\end{array}$ & China & Araliaceae & Frodin and Saponin & $\begin{array}{l}\text { Potent antiviral activity against } \\
\text { respiratory syncytial virus. }\end{array}$ & {$[46]$} \\
\hline 11 & Bergenia ligulata & Nepal & Saxifragaceae & Condensed Tannins & $\begin{array}{l}\text { Inhibits viral RNA synthesis and reduces } \\
\text { viral peptide synthesis. }\end{array}$ & {$[47]$} \\
\hline 12 & $\begin{array}{l}\text { Geranium } \\
\text { sanguineum }\end{array}$ & Bulgaria & Geraniaceae & Polyphenols & $\begin{array}{l}\text { Inhibition of influenza virus protein } \\
\text { synthesis. }\end{array}$ & {$[48]$} \\
\hline 13 & Sambucus nigra & Japan & Caprifoliaceae & $\begin{array}{l}\text { Kaempferol, astragalin, } \\
\text { quercetin, rutin, } \\
\text { isoquercitrin, hyperoside }\end{array}$ & $\begin{array}{l}\text { Neutralize and reduce the infectivity of } \\
\text { influenza viruses A and B. }\end{array}$ & {$[49]$} \\
\hline 14 & $\begin{array}{l}\text { Justicia } \\
\text { pectoralis }\end{array}$ & Latin America & Acanthaceae & $\begin{array}{l}\text { Coumarin and } \\
\text { umbelliferone }\end{array}$ & $\begin{array}{l}\text { Possess anti-inflammatory and relaxant } \\
\text { effects, and it supports recovery from } \\
\text { influenza. }\end{array}$ & {$[50]$} \\
\hline 15 & $\begin{array}{l}\text { Achillea } \\
\text { millefolium }\end{array}$ & N. hemisphere & Asteraceae & $\begin{array}{l}\text { Isovaleric acid, salicylic } \\
\text { acid, asparagin, sterols, } \\
\text { flavonoids, bitters, } \\
\text { tannins, and coumarins }\end{array}$ & $\begin{array}{l}\text { A chest rub from this extract can be } \\
\text { effective against influenza. }\end{array}$ & {$[51]$} \\
\hline 16 & Astragalus & $\begin{array}{l}\text { Temperate } \\
\text { region of } \mathrm{N} . \\
\text { hemisphere. }\end{array}$ & Fabaceae & Cycloastregenol & $\begin{array}{l}\text { Boosts the immune system thereby } \\
\text { provides shield against the Viral } \\
\text { infection. }\end{array}$ & {$[52]$} \\
\hline 17 & $\begin{array}{l}\text { Agathosma } \\
\text { betulina }\end{array}$ & $\begin{array}{l}\text { Western-South } \\
\text { Africa. }\end{array}$ & Rutaceae & $\begin{array}{l}\text { Isomenthone and } \\
\text { diosphenol }\end{array}$ & $\begin{array}{l}\text { Natural antiviral that has antioxidant \& } \\
\text { antiseptic activity \& helps the body get } \\
\text { rid itself of toxins. }\end{array}$ & {$[53]$} \\
\hline 19 & Olea europaea & $\begin{array}{l}\text { Mediterranean } \\
\text { Basin }\end{array}$ & Oleaceae & $\begin{array}{l}\text { Phenolic compounds } \\
\text { and oleuropein }\end{array}$ & $\begin{array}{l}\text { Natural antiviral; stimulates the immune } \\
\text { system. }\end{array}$ & {$[54]$} \\
\hline
\end{tabular}


Table 1: Continued.

\begin{tabular}{|c|c|c|c|c|c|c|}
\hline S. no. & $\begin{array}{l}\text { Plant and its } \\
\text { origin }\end{array}$ & Native & Family & $\begin{array}{l}\text { Principal chemical } \\
\text { compounds }\end{array}$ & Anti-influenza action & Reference \\
\hline 20 & Junipers & $\begin{array}{l}\text { Arctic region, } \\
\text { tropical Africa, } \\
\text { central America }\end{array}$ & Cupressaceae & $\begin{array}{l}\alpha \text {-pinene, camphene, } \\
\beta \text {-pinene, sabinene, } \\
\text { myrcene, } \\
\alpha \text {-phellandrene, } \\
\alpha \text {-terpinene }\end{array}$ & $\begin{array}{l}\text { It has high Macrophage } \\
\text { immunomodulatory efficacies. }\end{array}$ & {$[55]$} \\
\hline 21 & $\begin{array}{l}\text { Cinnamomum } \\
\text { verum }\end{array}$ & Sri Lanka & Lauraceae & $\begin{array}{l}\text { Cinnamaldehyde, gum, } \\
\text { tannin, mannitol }\end{array}$ & $\begin{array}{l}\text { Antioxidants and radical scavenger. } \\
\text { Prevents the entry of Virus. }\end{array}$ & {$[56]$} \\
\hline 22 & $\begin{array}{l}\text { Scutellaria } \\
\text { baicalensis }\end{array}$ & Japan & Lamiaceae & $\begin{array}{l}5,7,4^{\prime} \text {-trihydroxy- } 8- \\
\text { methoxyflavone }(\mathrm{F} 36) \\
\text { from the roots }\end{array}$ & $\begin{array}{l}\text { Reduces the replication of influenza virus } \\
\text { A/PR/8/34 (A/PR8) by inhibiting the } \\
\text { fusion of the virus with } \\
\text { endosome/lysosome membrane which } \\
\text { occurs at early stage of viral infection } \\
\text { cycle. }\end{array}$ & [57] \\
\hline 23 & $\begin{array}{l}\text { Chrysanthemum } \\
\text { indicum }\end{array}$ & India, China & Asteraceae & $\begin{array}{l}\alpha \text {-terpineol, cis-sabinol, } \\
\text { thujone, camphor }\end{array}$ & $\begin{array}{l}\text { Chrysanthemum tea has many purported } \\
\text { medicinal uses, including an aid in } \\
\text { recovery from influenza. }\end{array}$ & {$[58]$} \\
\hline
\end{tabular}

TABLE 2: List of medicinal plants, from all over the world, which may prove useful in combating novel H1N1 flu by stimulating immune system.

\begin{tabular}{|c|c|c|c|c|c|}
\hline $\begin{array}{l}\text { Plant and its } \\
\text { origin }\end{array}$ & Native & Family & Principal chemical compounds & Anti-influenza action & Reference \\
\hline $\begin{array}{l}\text { Quillaja } \\
\text { saponaria }\end{array}$ & $\begin{array}{l}\text { Central } \\
\text { Chile }\end{array}$ & Quillajaceae & $\begin{array}{l}\text { Glucoside saponin, tannins, } \\
\text { polyphenols, calcium oxalate }\end{array}$ & $\begin{array}{l}\text { Facilitate the removal of phlegm } \\
\text { through coughing, hence aids in passive } \\
\text { immunity. }\end{array}$ & {$[65]$} \\
\hline $\begin{array}{l}\text { Echinacea } \\
\text { purpurea }\end{array}$ & $\begin{array}{l}\text { North } \\
\text { America }\end{array}$ & Compositae & Cichoric acid, ethanol- and ethyl acetate & $\begin{array}{l}\text { Echinacea increases the levels of a } \\
\text { chemical called properdin in the body } \\
\text { which activates part of the immune } \\
\text { system responsible for increasing the } \\
\text { defence mechanisms against bacteria } \\
\text { and viruses. It is also a potent anti-viral } \\
\text { photosensitizer. }\end{array}$ & {$[66]$} \\
\hline $\begin{array}{l}\text { Salvia } \\
\text { officinalis }\end{array}$ & $\begin{array}{l}\text { Central and } \\
\text { Southwest- } \\
\text { ern Asia, } \\
\text { Mexico }\end{array}$ & Lamiaceae & $\begin{array}{l}\text { 4-hydroxy-acetophenone- } 4-\mathrm{O}-\beta \text {-D- } \\
\text { apiofuranosyl- }(1 \rightarrow 6)-\mathrm{O}-\beta \text {-D- } \\
\text { glucopyranoside }\end{array}$ & $\begin{array}{l}\text { Salviae extract increased the levels of } \\
\text { influenza virus specific antibodies and } \\
\text { neutralizing activities also acts as } \\
\text { mucosal adjuvant and immune } \\
\text { modulator during influenza virus } \\
\text { infection. }\end{array}$ & {$[67]$} \\
\hline $\begin{array}{l}\text { Nicotiana } \\
\text { benthamiana }\end{array}$ & Australia & Solanaceae & Capsanthin, Carotenoids, glycolipids. & $\begin{array}{l}\text { Induce a protective immune response } \\
\text { against a lethal influenza viral challenge } \\
\text { in mice against the influenza. }\end{array}$ & {$[68]$} \\
\hline Ginkgo biloba & $\begin{array}{l}\text { China and } \\
\text { Japan }\end{array}$ & Ginkgoaceae & $\begin{array}{l}\text { Flavonoid glycosides and terpenoids } \\
\text { (ginkgolides, bilobalides) }\end{array}$ & $\begin{array}{l}\text { Ginkgo, improves blood flow and } \\
\text { improves immunity. }\end{array}$ & {$[69]$} \\
\hline $\begin{array}{l}\text { Thuja } \\
\text { occidentalis }\end{array}$ & $\begin{array}{l}\text { North } \\
\text { America, } \\
\text { Europe }\end{array}$ & Cupressaceae & Thujone, Vitamin C & $\begin{array}{l}\text { Leukocyte and cytokine induction, } \\
\text { increases antibody response. }\end{array}$ & {$[70]$} \\
\hline $\begin{array}{l}\text { Withania } \\
\text { somnifera }\end{array}$ & India & Solanaceae & $\begin{array}{l}\text { Anaferine, anahygrine, beta-sisterol, } \\
\text { chlorogenic acid, cysteine, } \\
\text { cuscohygrine, pseudotropine, } \\
\text { scopoletin, somniferinine, withaferin } \alpha \text {, } \\
\text { withanine, withananine, and } \\
\text { withanolides }\end{array}$ & $\begin{array}{l}\text { Stimulant for the immune system, also a } \\
\text { very potent adaptogen. }\end{array}$ & {$[71]$} \\
\hline
\end{tabular}


genomic and proteomic approaches and nanotechnologybased antiviral drug development. It is anticipated that rapid advances in the field of bioinformatics would lead in the future to improvisation of antiviral effectiveness of phytocompounds, via virtual antiviral screening of phytocompounds, for effective management of H1N1 flu.

Figure 7 summarizes some of the medicinal plants.

\section{Conclusion}

Pandemic influenza has posed a global threat, though currently the situation is fairly under control. However, the society remains insufficiently equipped to handle the outbreak from resistant strains if they were to occur despite many years of advance warning and preparation to handle such casualties. Mainstream medicine currently does not have a vaccine. The vaccine when available would be stockpiled along with antiviral drugs for use to handle crisis emerging. However, immediately after the launch it would be in short supply and ineffective, in a pandemic situation, for treating the masses in developing and underdeveloped nations. Besides the development of drug resistance, emergence of mutant strains of the virus, emergence of a more virulent strain, prohibitive costs of available drugs, time lag between vaccine development, and mass casualties would pose really difficult problems. In view of this, complementary and alternative medicine offers a plethora of interesting possibilities to help patients. Herbs exhibit a diverse array of biological activities and can be effectively harnessed for managing pandemic flu. It is evident that nutritional and botanical approaches, taken together, provide very potent tools for controlling an array of viral infections. It is unfortunate that many of these herbs have been overlooked, and the initial exciting research findings have not been followed up with larger, more rigorous clinical trials. The availability of a wide range of potentially active herbs and constituents, to potentiate as anti-influenza agents, may have a leading role in the ongoing struggle against the novel H1N1 infection. Herbal drugs would be useful, but it should not be expected as a panacea for offering perfect protection or absolute cessation of symptoms, but could be instead helpful in achieving reduced risk, symptom reduction, and quicker recovery. This paper portrays an eclectic overview for the treatment of pandemic influenza and covers some of the herbs that are most likely to be of deal help in managing the current pandemic scenario and also to cope with the next pandemic that might appear in the not-too-distant future. It is our firm belief that the plants discussed in the paper would also be useful in treating the patients with serious influenza in nonpandemic situations too.

\section{Acknowledgments}

The authors are thankful to DRDO, Ministry of Defence, Government of India, for funding and support. The authors declare no conflict of interests and strongly advocate that self-medication be avoided.

\section{References}

[1] L. M. Alleva, C. Charles, and I. A. Clark, "Using complementary and alternative medicines to target the host response during severe influenza," Evidence-Based Complementary and Alternative Medicine, vol. 7, no. 4, pp. 501-510, 2010.

[2] "Serum cross-reactive antibody response to a novel influenza A (H1N1) virus after vaccination with seasonal influenza vaccine," Morbidity and Mortality Weekly Report, vol. 58, no. 19, pp. 521-524, 2009.

[3] F. Hayden, "Developing new antiviral agents for influenza treatment: what does the future hold?" Clinical Infectious Diseases, vol. 48, no. 1, pp. S3-S13, 2009.

[4] R. Chawla, R. K. Sharma, D. Madaan et al., "Mitigation approaches to combat flu pandemic," Journal of Global Infectious Diseases, vol. 1, no. 2, pp. 117-130, 2009.

[5] J. P. Lynch III and E. E. Walsh, "Influenza: evolving strategies in treatment and prevention," Seminars in Respiratory and Critical Care Medicine, vol. 28, no. 2, pp. 144-158, 2007.

[6] R. A. Bright, M.-J. Medina, X. Xu et al., "Incidence of adamantane resistance among influenza A (H3N2) viruses isolated worldwide from 1994 to 2005: a cause for concern," Lancet, vol. 366, no. 9492, pp. 1175-1181, 2005.

[7] "Swine influenza: frequently asked questions," Weekly Epidemiological Record. World Health Organization, vol. 84, no. 18, pp. 149-160, 2009.

[8] B. Patwardhan, D. Warude, P. Pushpangadan, and N. Bhatt, "Ayurveda and traditional Chinese medicine: a comparative overview," Evidence-Based Complementary and Alternative Medicine, vol. 2, no. 4, pp. 465-473, 2005.

[9] K. Kaphle, L.-S. Wu, N.-Y. J. Yang, and J.-H. Lin, "Herbal medicine research in Taiwan," Evidence-Based Complementary and Alternative Medicine, vol. 3, no. 1, pp. 149-155, 2006.

[10] H. Kiyohara, K. Nonaka, M. Sekiya et al., "Polysaccharidecontaining macromolecules in a kampo (traditional Japanese herbal) medicine, hochuekkito: dual active ingredients for modulation of immune functions on intestinal Peyer's patches and epithelial cells," Evidence-Based Complementary and Alternative Medicine. In press.

[11] H. Azaizeh, B. Saad, E. Cooper, and O. Said, "Traditional arabic and islamic medicine, a re-emerging health aid," Evidence-Based Complementary and Alternative Medicine, vol. 7, no. 4, pp. 419-424, 2010.

[12] F. Firenzuoli and L. Gori, "Herbal medicine today: clinical and research issues," Evidence-Based Complementary and Alternative Medicine, vol. 4, no. 1, pp. 37-40, 2007.

[13] I.-M. Chang, "Initiative for developing evidence-based standardization of traditional Chinese medical therapy in the western pacific region of the World Health Organization," Evidence-Based Complementary and Alternative Medicine, vol. 1, no. 3, pp. 337-341, 2004.

[14] L. Mishra and C. Lakshmi, Scientific Basis for Ayurvedic Therapies, CIRC Press, 2004.

[15] X. Wang, W. Jia, A. Zhao, and X. Wang, "Anti-influenza agents from plants and traditional Chinese medicine," Phytotherapy Research, vol. 20, no. 5, pp. 335-341, 2006.

[16] P. K. Warrier, Indian 9 Medicinal Plants, vol. 4, Orient Longman, 1995.

[17] F. Curreli, A. E. Friedman-Kien, and O. Flore, "Glycyrrhizic acid alters Kaposi sarcoma-associated herpesvirus latency, triggering p53-mediated apoptosis in transformed B lymphocytes," Journal of Clinical Investigation, vol. 115, no. 3, pp. 642-652, 2005. 
[18] M. Nose, K. Terawaki, K. Oguri, Y. Ogihara, K. Yoshimatsu, and K. Shimomura, "Activation of macrophages by crude polysaccharide fractions obtained from shoots of Glycyrrhiza glabra and hairy roots of Glycyrrhiza uralensis in vitro," Biological and Pharmaceutical Bulletin, vol. 21, no. 10, pp. 1110-1112, 1998.

[19] H. Wagner and K. Jurcic, "Immunological studies of Revitonil ${ }^{\circledR}$, a phytopharmaceutical containing Echinacea purpurea and Glycyrrhiza glabra root extract," Phytomedicine, vol. 9, no. 5, pp. 390-397, 2002.

[20] C. Fiore, M. Eisenhut, R. Krausse et al., "Antiviral effects of Glycyrrhiza species," Phytotherapy Research, vol. 22, no. 2, pp. 141-148, 2008.

[21] R. Pompei, O. Flore, and M. A. Marccialis, "Glycyrrhizic acid inhibits virus growth and inactivates virus particles," Nature, vol. 281, no. 5733, pp. 689-690, 1979.

[22] P. K. Warrier, Indian 9 Medicinal Plants, vol. 5, Orient Longman, 1995.

[23] M. Kuhn and D. Winston, Winston \& Kuhn's Herbal Therapy \& Supplements: A Scientific and Traditional Approach, Lippincott Williams \& Wilkins, Philadelphia, Pa, USA, 2007.

[24] NIIR Board, Compendium of Medicinal Plants, National Institute of Industrial Research, New Delhi, India, 2004.

[25] P. Prakash and N. Gupta, "Therapeutic uses of Ocimum sanctum Linn (O. sanctum) with a note on eugenol and its pharmacological actions," Indian Journal of Physiology and Pharmacology, vol. 10, no. 1, pp. 23-25, 1972.

[26] J. Sethi, S. Sood, S. Seth, and A. Talwar, "Evaluation of hypoglycemic and antioxidant effect of Ocimum sanctum," Indian Journal of Clinical Biochemistry, vol. 19, no. 2, pp. 152155, 2004.

[27] P. Uma Devi and A. Ganasoundari, "Modulation of glutathione and antioxidant enzymes by Ocimum sanctum and its role in protection against radiation injury," Indian Journal of Experimental Biology, vol. 37, no. 3, pp. 262-268, 1999.

[28] R. Arora, D. Gupta, R. Chawla et al., "Radioprotection by plant products: present status and future prospects," Phytotherapy Research, vol. 19, no. 1, pp. 1-22, 2005.

[29] R. N. Chopra, S. L. Nayer, and I. C. Chopra, Glossary of Indian Medicinal Plants, Council of Scientific and Industrial Research, New Delhi, India, 1956.

[30] S. A. Phadke and S. D. Kulkarni, "Screening of in vitro antibacterial activity of Terminalia chebula, Eclapta alba and Ocimum sanctum," Indian Journal of Medical Sciences, vol. 43, no. 5, pp. 113-117, 1989.

[31] M. K. Rai, "In vitro evaluation of medicinal plant extracts against Pestalotiopsis mangiferae," Hindustan Antibiotics Bulletin, vol. 38, no. 1-4, pp. 53-56, 1996.

[32] R. Kumar, D. P. Singh, V. K. Chaturvedi, and R. C. Pathak, "A note on anti viral property of neem (Melia azadirachata) and O. sanctum (Ocimum sanctum) against Newcastle disease virus," Journal of Comparative Microbiology, Immunology and Infectious Diseases, vol. 18, p. 192, 1997.

[33] S. Gupta, P. Sharma, and B. M. Saini, "Immunomodulatory potential of Ocimum tenuiflorum extracts in bovine peripheral blood mononuclear cells in vitro," Journal of Immunology and Immunopathology, vol. 9, 2007.

[34] S. A. Phadke and S. D. Kulkarni, "Screening of in vitro antibacterial activity of Terminalia chebula, Eclapta alba and Ocimum sanctum," Indian Journal of Medical Sciences, vol. 43, no. 5, pp. 113-117, 1989.
[35] Y. Tsai, L. L. Cole, L. E. Davis, S. J. Lockwood, V. Simmons, and G. C. Wild, "Antiviral properties of garlic: in vitro effects on influenza B, herpes simplex and Coxsackie viruses," Planta Medica, no. 5, pp. 460-461, 1985.

[36] N. Guo, D. Lu, G. L. Woods et al., "Demonstration of the anti-viral activity of garlic extract against human cytomegalovirus in vitro," Chinese Medical Journal, vol. 106, no. 2, pp. 93-96, 1993.

[37] V. Subhose, P. Srinivas, and A. Narayana, "Basic principles of pharmaceutical science in Ayurvěda," Bulletin of the Indian Institute of History of Medicine, vol. 35, no. 2, pp. 83-92, 2005.

[38] L. G. Miller, "Herbal medicinals: selected clinical considerations focusing on known or potential drug-herb interactions," Archives of Internal Medicine, vol. 158, no. 20, pp. 2200-2211, 1998.

[39] M. Wirotesangthong, T. Nagai, H. Yamada, S. Amnuoypol, and C. Mungmee, "Effects of Clinacanthus siamensis leaf extract on influenza virus infection," Microbiology and Immunology, vol. 53, no. 2, pp. 66-74, 2009.

[40] K. Mochida, "Anti-influenza virus activity of Myrica rubra leaf ethanol extract evaluated using Madino-Darby canine kidney (MDCK) cells," Bioscience, Biotechnology and Biochemistry, vol. 72, no. 11, pp. 3018-3020, 2008.

[41] L. S. M. Ooi, L. Tian, M. Su et al., "Isolation, characterization, molecular cloning and modeling of a new lipid transfer protein with antiviral and antiproliferative activities from Narcissus tazetta," Peptides, vol. 29, no. 12, pp. 2101-2109, 2008.

[42] S. Yingsakmongkon, D. Miyamoto, N. Sriwilaijaroen et al., "In vitro inhibition of human influenza A virus infection by fruit-juice concentrate of Japanese plum (Prunus mume SIEB. et ZUCC)," Biological and Pharmaceutical Bulletin, vol. 31, no. 3, pp. 511-515, 2008.

[43] C. Ehrhardt, E. R. Hrincius, V. Korte et al., "A polyphenol rich plant extract, CYSTUS052, exerts anti influenza virus activity in cell culture without toxic side effects or the tendency to induce viral resistance," Antiviral Research, vol. 76, no. 1, pp. 38-47, 2007.

[44] L. S. M. Ooi, S. S. M. Sun, and V. E. C. Ooi, "Purification and characterization of a new antiviral protein from the leaves of Pandanus amaryllifolius (Pandanaceae)," International Journal of Biochemistry and Cell Biology, vol. 36, no. 8, pp. 1440-1446, 2004.

[45] Y. B. Ryu, M. J. Curtis-Long, J. H. Kim et al., "Pterocarpans and flavanones from Sophora flavescens displaying potent neuraminidase inhibition," Bioorganic and Medicinal Chemistry Letters, vol. 18, no. 23, pp. 6046-6049, 2008.

[46] S. V. Valcheva-Kuzmanova and A. Belcheva, "Current knowledge of Aronia melanocarpa as a medicinal plant," Folia Medica, vol. 48, no. 2, pp. 11-17, 2006.

[47] Y. Li, R. Jiang, L. S. M. Ooi, P. P. H. But, and V. E. C. Ooi, "Antiviral triterpenoids from the medicinal plant Schefflera heptaphylla," Phytotherapy Research, vol. 21, no. 5, pp. 466470, 2007.

[48] M. Rajbhandari, U. Wegner, T. Schöpke, U. Lindequist, and R. Mentel, "Inhibitory effect of Bergenia ligulata on influenza virus A," Pharmazie, vol. 58, no. 4, pp. 268-271, 2003.

[49] J Serkedjieva and N. Manolova, "Plant polyphenolic complex inhibits the reproduction of influenza and herpes simplex viruses," Phytotherapy Research, vol. 10, no. 5, pp. 441-443, 1999.

[50] C. Kappagoda, D. Isaacs, C. Mellis, J. Peat, L. De Silva, and A. O'Connell, "Critical influenza virus infection," Journal of 
Paediatrics and Child Health, vol. 36, no. 4, pp. 318-321, 2000.

[51] de la Osa, Comisión Técnica de Fitomed (CTF) [2003], José Gripe, November 2008.

[52] T. Skwarek, "Effects of Herbal Preparations on the propagation of influenza viruses," Acta Poloniae Pharmaceulica, vol. 36, no. 5, pp. 1-7, 1979.

[53] J. L. Ríos and P. G. Waterman, "A review of the pharmacology and toxicology of Astragalus," Phytotherapy Research, vol. 11, no. 6, pp. 411-418, 1998.

[54] M. Lis-Balchin, S. Hart, and E. Simpson, "Buchu (Agathosma betulina and A. crenulata, Rutaceae) essential oils: their pharmacological action on guinea-pig ileum and antimicrobial activity on microorganisms," Journal of Pharmacy and Pharmacology, vol. 53, no. 4, pp. 579-582, 2001.

[55] R. Lumaret and N. Ouazzani, "Ancient wild olives in Mediterranean forests," Nature, vol. 413, no. 6857, p. 700, 2001.

[56] I. A. Schepetkin, C. L. Faulkner, L. K. Nelson-Overton, J. A. Wiley, and M. T. Quinn, "Macrophage immunomodulatory activity of polysaccharides isolated from Juniperus scopolorum," International Immunopharmacology, vol. 5, no. 13-14, pp. 1783-1799, 2005.

[57] S. Mathew and T. E. Abraham, "In vitro antioxidant activity and scavenging effects of Cinnamomum verum leaf extract assayed by different methodologies," Food and Chemical Toxicology, vol. 44, no. 2, pp. 198-206, 2006.

[58] T. Nagai, R. Moriguchi, Y. Suzuki, T. Tomimori, and H. Yamada, "Mode of action of the anti-influenza virus activity of plant flavonoid, 5,7,4'-trihydroxy-8-methoxyflavone, from the roots of Scutellaria baicalensis," Antiviral Research, vol. 26, no. 1, pp. 11-25, 1995.

[59] W. Duke, “Medicine: Cocos nucifera Folk Medicine," 2009.

[60] J. J. Kabara, The Pharmacological Effect of Lipids, American Oil Chemist's Society, Champaign, Ill, USA, 1978.

[61] S. J. Projan, S. B. Skrobot, P. M. Schlievert, F. Vandenesch, and R. P. Novick, "Glycerol monolaurate inhibits the production of beta-lactamase, toxic shock toxin1, and other staphylococcal exoproteins By interfering with signal transduction," Journal of Bacteriology, vol. 176, pp. 4204-4209, 1996.

[62] B. Hornung, E. Amtmann, and G. Sauer, "Lauric acid inhibits the maturation of vesicular stomatitis virus," Journal of General Virology, vol. 75, no. 2, pp. 353-361, 1994.

[63] S. O. Kim, J. K. Kundu, Y. K. Shin et al., "Gingerol inhibits COX-2 expression by blocking the activation of p38 MAP kinase and NF-kappaB in phorbol ester-stimulated mouse skin," American Society for Nutrition Journal of Nutrition, vol. 136, pp. 1150-1155, 2006.

[64] X. Wang, W. Jia, A. Zhao, and X. Wang, "Anti-influenza agents from plants and traditional Chinese medicine," Phytotherapy Research, vol. 20, no. 5, pp. 335-341, 2006.

[65] M. Villacres-Eriksson, S. Behboudi, A. J. Morgan, G. Trinchieri, and B. Morein, "Immunomodulation by Quillaja saponaria adjuvant formulations: in vivo stimulation of interleukin 12 and its effects on the antibody response," Cytokine, vol. 9, no. 2, pp. 73-82, 1997.

[66] S. H. Yale and K. Liu, "Echinacea purpurea therapy for the treatment of the common cold: a randomized, doubleblind, placebo-controlled clinical trial," Archives of Internal Medicine, vol. 164, no. 11, pp. 1237-1241, 2004.

[67] K. H. T. Benny, B. H. Bay, and Y. Z. Zhu, Novel Compounds from Natural Products in the New Millennium: Potential and Challenges, World Scientific, Singapore, 2004.
[68] M.-A. D’Aoust, P.-O. Lavoie, M. M.-J. Couture et al., "Influenza virus-like particles produced by transient expression in Nicotiana benthamiana induce a protective immune response against a lethal viral challenge in mice," Plant Biotechnology Journal, vol. 6, no. 9, pp. 930-940, 2008.

[69] M. M. Villaseñor-García, X. Lozoya, L. Osuna-Torres, J. M. Viveros-Paredes, L. Sandoval-Ramírez, and A. M. Puebla-Pérez, "Effect of Ginkgo biloba extract EGb 761 on the nonspecific and humoral immune responses in a hypothalamic-pituitary-adrenal axis activation model," International Immunopharmacology, vol. 4, no. 9, pp. 12171222, 2004.

[70] B. Naser, C. Bodinet, M. Tegtmeier, and U. Lindequist, "Thuja occidentalis (Arbor vitae): a review of its pharmaceutical, pharmacological and clinical properties," EvidenceBased Complementary and Alternative Medicine, vol. 2, no. 1, pp. 69-78, 2005.

[71] G. Guenther, R Krishna, and W. Badhwar, "Controlled clinical study of Trachyspermum ammi," Journal of Scientific \& Industrial Research, vol. 12A, no. 2, pp. 288-289, 1953.

[72] A. Sànchez-Lamar, M. Fiore, E. Cundari, R. Ricordy, R. Cozzi, and R. De Salvia, "Phyllanthus orbicularis aqueous extract: cytotoxic, genotoxic, and antimutagenic effects in the $\mathrm{CHO}$ cell line," Toxicology and Applied Pharmacology, vol. 161, no. 3, pp. 231-239, 1999.

[73] M. N. Fortunatov, "Experimental use of phytoncides for therapeutic and prophylactic purpose," Voprosy Pediatrii $i$ Okhrany Materinstva, vol. 20, no. 2, pp. 55-58, 1952.

[74] W. David and M. Steven, Adaptogens: Herbs for Strength, Stamina, and Stress Relief, Healing Arts Press, 2007.

[75] S. S. Singh, S. C. Pandey, S. Srivastava, V. S. Gupta, B. Patro, and A. C. Ghosh, "Chemistry and medicinal properties of Tinospora cordifolia (Guduchi)," Indian Journal of Pharmacology, vol. 35, no. 2, pp. 83-91, 2003.

[76] A. Kapil and S. Sharma, "Immunopotentiating compounds from Tinospora cordifolia," Journal of Ethnopharmacology, vol. 58, no. 2, pp. 89-95, 1997.

[77] Y. R. Sohni and R. M. Bhatt, "Activity of a crude extract formulation in experimental hepatic amoebiasis and in immunomodulation studies," Journal of Ethnopharmacology, vol. 54, no. 2-3, pp. 119-124, 1996.

[78] A. Peirce, The American Pharmaceutical Association Practical Guide to Natural Medicines, William Morrow, New York, NY, USA, 1999.

[79] M. T. Murray, The Healing Power of Herbs: The Enlightened Person's Guide to the Wonders of Medicinal Plants, vol. 25, Prima, Rocklin, Calif, USA, 1995.

[80] E. C. Herrmann Jr. and L. S. Kucera, "Antiviral substances in plants of the mint family (labiatae). 3. Peppermint (Mentha piperita) and other mint plants," Proceedings of the Society for Experimental Biology and Medicine, vol. 124, no. 3, pp. 874878, 1967.

[81] E. C. Herrmann Jr. and L. S. Kucera, "Antiviral substances in plants of the mint family (labiatae). 3. Peppermint (Mentha piperita) and other mint plants," Proceedings of the Society for Experimental Biology and Medicine, vol. 124, no. 3, pp. 874878, 1967.

[82] R. Valsaraj, P. Pushpangadan, U. W. Smitt, A. Adsersen, and U. Nyman, "Antimicrobial screening of selected medicinal plants from India," Journal of Ethnopharmacology, vol. 58, no. 2, pp. 75-83, 1997.

[83] S. Ganguli, "Neem: a therapeutic for all seasons," Current Science, vol. 82, no. 11, p. 1304, 1994. 
[84] M. M. Parida, C. Upadhyay, G. Pandya, and A. M. Jana, "Inhibitory potential of neem (Azadirachta indica Juss) leaves on dengue virus type-2 replication," Journal of Ethnopharmacology, vol. 79, no. 2, pp. 273-278, 2002.

[85] L. Badam, S. P. Joshi, and S. S. Bedekar, 'In vitro' antiviral activity of neem (Azadirachta indica. A. Juss) leaf extract against group B Coxsackieviruses," Journal of Communicable Diseases, vol. 31, no. 2, pp. 79-90, 1999.

[86] R. Arora, S. Singh, and R. K. Sharma, "Neem leaves: Indian herbal medicine," in Botanical Medicine in Clinical Practice, R. R. Watson and V. R. Preedy, Eds., pp. 85-98, CAB International, Oxon, UK, 2008.

[87] A. Chatterjee, "Isolation of allo-imperatorin and $\beta$-sitosterol from the fruits of Aegle marmelos Correa," Journal of the Indian Chemical Society, vol. 34, no. 3, pp. 228-230, 1957.

[88] G. Guenther, R. Krishna, and W. Badhwar, "Controlled clinical study of Trachyspermum ammi," Journal of Scientific \& Industrial Research, vol. 12A, no. 2, pp. 288-289, 1953.

[89] R. N. Chopra, S. L. Nayar, and I. C. Chopra, Glossary of Indian Medicinal Plants (Including the Supplement), Council of Scientific and Industrial Research, New Delhi, India, 1986.

[90] D. Bown, Encyclopaedia of Herbs and Their Uses, Dorling Kindersley, London, UK, 1995.

[91] J. Melchior, S. Palm, and G. Wikman, "Controlled clinical study of standardized Andrographis paniculata extract in common cold: a pilot trial," Phytomedicine, vol. 34, pp. 314318, 1996-1997.

[92] G. H. Naik, K. I. Priyadarsini, D. B. Naik, R. Gangabhagirathi, and H. Mohan, "Studies on the aqueous extract of Terminalia chebula as a potent antioxidant and a probable radioprotector," Phytomedicine, vol. 11, no. 6, pp. 530-538, 2004.

[93] H.-Y. Cheng, T.-C. Lin, K.-H. Yu, C.-M. Yang, and C.-C. Lin, "Antioxidant and free radical scavenging activities of Terminalia chebula," Biological and Pharmaceutical Bulletin, vol. 26, no. 9, pp. 1331-1335, 2003.

[94] A. Schwarte, "Phytochemische und pharmakologische Untersuchungen der Wurzeln von Sophora flavescens, unter besonderer Berücksichtigung ihrer Wirkung auf die Leukotrien- und Prostaglandinbiosynthese," 2002.

[95] Y.-P. Zhu, Chinese Materia Medica: Chemistry, Pharmacology and Applications, CRC Press, Boca Raton, Fla, USA, 1998.

[96] A. Schwarte, "Phytochemische und pharmakologische Untersuchungen der Wurzeln von Sophora flavescens, unter besonderer Berücksichtigung ihrer Wirkung auf die Leukotrien- und Prostaglandinbiosynthese," 2002.

[97] K. Sasaki, N. Minowa, H. Kuzuhara, S. Nishiyama, and S. Omoto, "Synthesis and hepatoprotective effects of soyasapogenol B derivatives," Bioorganic and Medicinal Chemistry Letters, vol. 7, no. 1, pp. 85-88, 1997.

[98] P. Zheng, F.-L. Niu, W.-Z. Liu, Y. Shi, and L.-G. Lu, "Anti-inflammatory mechanism of oxymatrine in dextran sulfate sodium-induced colitis of rats," World Journal of Gastroenterology, vol. 11, no. 31, pp. 4912-4915, 2005.

[99] W. F. Chiou, C. C. Chen, and B. L. Wei, "8-prenylkaempferol suppresses influenza A virus-induced RANTES production in A549 cells via blocking PI3K-mediated transcriptional activation of NF-kappaB and IRF3," Evidence-Based Complementary and Alternative Medicine. In press.

[100] A. D. Kinghorn, M. F. Balandrin, and S. W. Pelletier, Alkaloids: Chemical and Biological Perspectives, vol. 3, John Wiley \& Sons, New York, NY, USA, 1984.
[101] M. Rajkumar, R. H. Chandra, K. Asres, and C. Veeresham, "Toddalia asiatica (Linn.) Lam.- a comprehensive review," Plant Review, vol. 12, no. 4, pp. 386-397, 2008.

[102] V. K. Saxena and R. N. Sharma, "Antimicrobial activity of the essential oil of Toddalia asiatica," Fitoterapia, vol. 70, no. 1, pp. 64-66, 1999.

[103] P. P. Lowry II, G. M. Plunkett, and J. Wen, "Generic relationships in Araliaceae: looking into the crystal ball," South African Journal of Botany, vol. 70, no. 3, pp. 382-392, 2004.

[104] G. M. Plunkett, J. Wen, and P. P. Lowry II, "Infrafamilial classifications and characters in Araliaceae: insights from the phylogenetic analysis of nuclear (ITS) and plastid (trnL-trnF) sequence data," Plant Systematics and Evolution, vol. 245, no. 1-2, pp. 1-39, 2004.

[105] G. M. Plunkett, P. P. Lowry II, D. G. Frodin, and J. Wen, "Phylogeny and geography of Schefflera: pervasive polyphyly in the largest genus of Araliaceae," Annals of the Missouri Botanical Garden, vol. 92, no. 2, pp. 202-224, 2005.

[106] Y. Li, R. Jiang, L. S. M. Ooi, P. P. H. But, and V. E. C. Ooi, "Antiviral triterpenoids from the medicinal plant Schefflera heptaphylla," Phytotherapy Research, vol. 21, no. 5, pp. 466470, 2007.

[107] Y. Li, P. P. H. But, and V. E. C. Ooi, "Antiviral activity and mode of action of caffeoylquinic acids from Schefflera heptaphylla (L.) Frodin," Antiviral Research, vol. 68, no. 1, pp. $1-9,2005$.

[108] J. M. Song, K. D. Park, K. H. Lee et al., "Biological evaluation of anti-influenza viral activity of semi-synthetic catechin derivatives," Antiviral Research, vol. 76, no. 2, pp. 178-185, 2007.

[109] K. S. Jennifer, D. Tamara, and K. Stefan, "North American (Panax quinquefolius) and Asian Ginseng (Panax ginseng) preparations for prevention of the common cold in healthy adults: a systematic review," Evidence-Based Complementary and Alternative Medicine. In press.

[110] Q. Xiang and P. P. Lowry, "Panax quinquefolius," in Flora of China, 13, Z. Y. Wu, P. H. Raven, and D. Y. Hong, Eds., p. 491, Science Press, Beijing, China; Missouri Botanical Garden Press, St. Louis, Mo, USA, 2007.

[111] S. Zhu, K. Zou, H. Fushimi, S. Cai, and K. Komatsu, "Comparative study on triterpene saponins of ginseng drugs," Planta Medica, vol. 70, no. 7, pp. 666-677, 2004.

[112] F. Scaglione, G. Cattaneo, M. Alessandria, and R. Cogo, "Efficacy and safety of the standardized ginseng extract G 115 for potentiating vaccination against common cold and/or influenza syndrome," Drugs under Experimental and Clinical Research, vol. 22, no. 2, pp. 65-72, 1996.

[113] B. Paul, Healing Power of Echinacea and Goldenseal and Other Immune System Herbs (The Healing Power), Prima Lifestyles, 1997.

[114] M. Dorn, "Milderung grippaler Effekte durch ein pflanzliches Immunstimulans," Natur und Ganzheitsmedizin, vol. 2, pp. 314-319, 1989.

[115] R. Brinkeborn, D. Shah, and S. Geissbuhler, "Echinaforce in the treatment of acute colds," Schweizerische Zeitschrift fur Ganzheits Medizin, vol. 10, pp. 26-29, 1998.

[116] H. Wagner, "Echinacea species as potential immunostimulatory drugs," Economic and Medicinal Plant Research, vol. 5, pp. 253-321, 1991.

[117] H. Wagner, A. Proksch, and I. Riess-Maurer, "Immunostimulating polysaccharides (heteroglycans) of higher plants," Arzneimittel-Forschung, vol. 35, no. 7, pp. 1069-1075, 1985. 
[118] M. Stimpel, A. Proksch, H. Wagner, and M.-L. LohmannMatthes, "Macrophage activation and induction of macrophage cytotoxicity by purified polysaccharide fractions from the plant Echinacea purpurea," Infection and Immunity, vol. 46, no. 3, pp. 845-849, 1984.

[119] B. Luettig, C. Steinmuller, G. E. Gifford, H. Wagner, and M.-L. Lohmann-Matthes, "Macrophage activation by the polysaccharide arabinogalactan isolated from plant cell cultures of Echinacea purpurea," Journal of the National Cancer Institute, vol. 81, no. 9, pp. 669-675, 1989. 


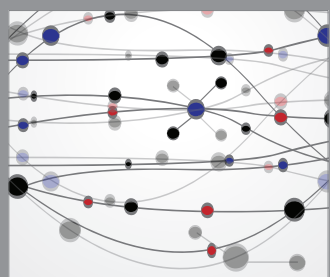

The Scientific World Journal
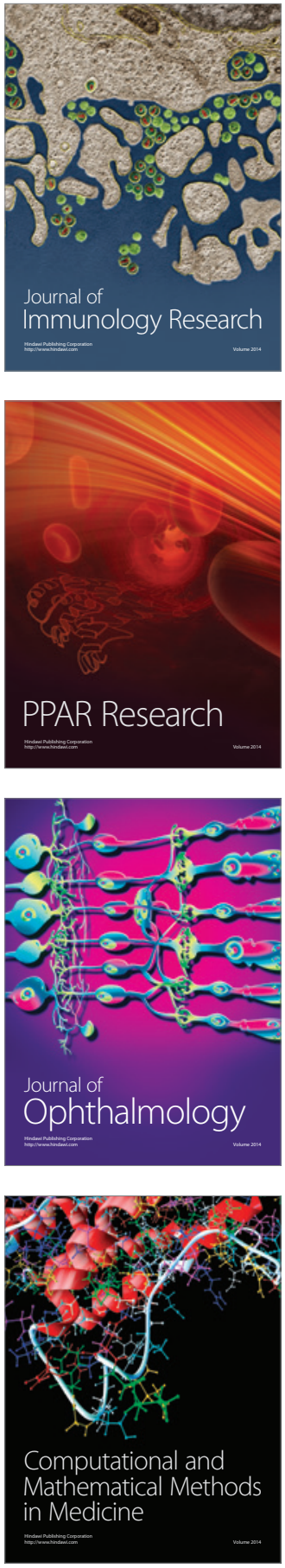



Gastroenterology

Research and Practice
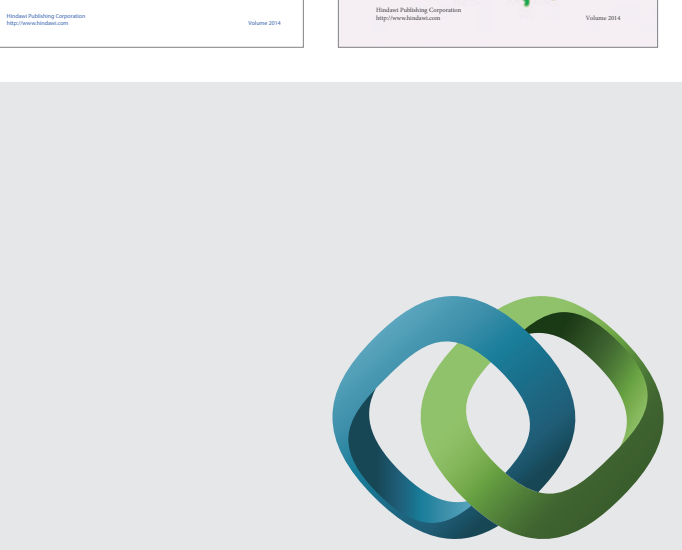

\section{Hindawi}

Submit your manuscripts at

http://www.hindawi.com
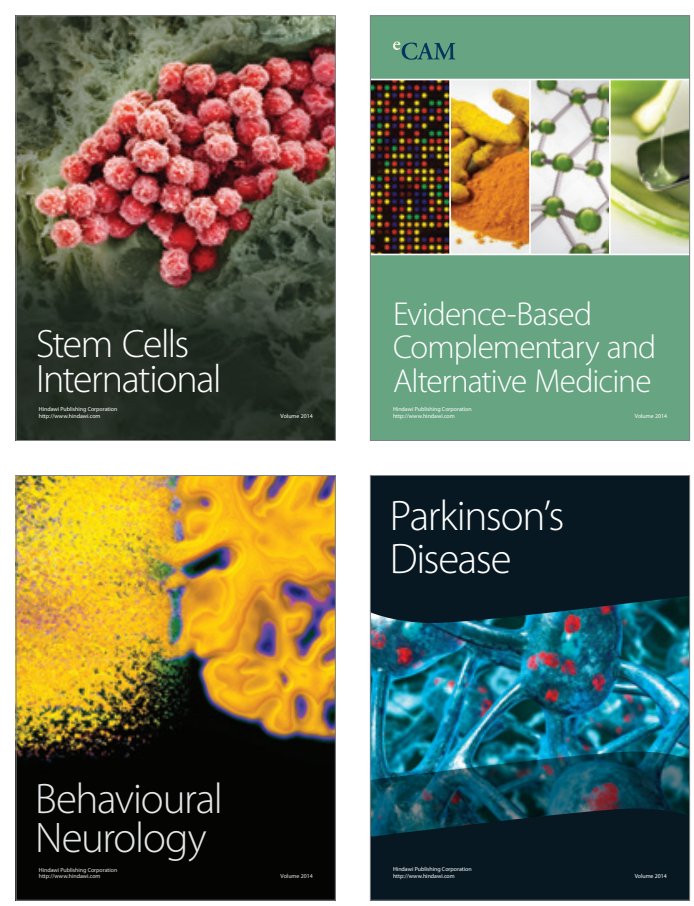

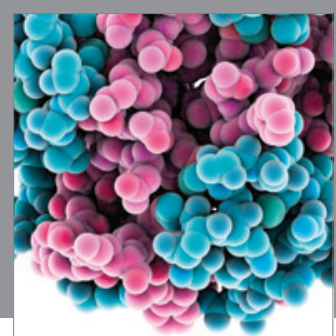

Journal of
Diabetes Research

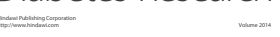

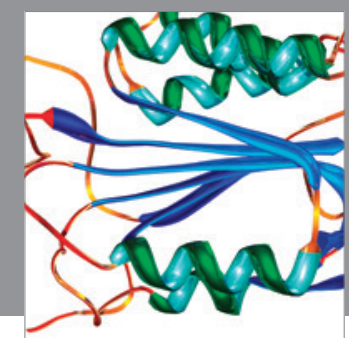

Disease Markers
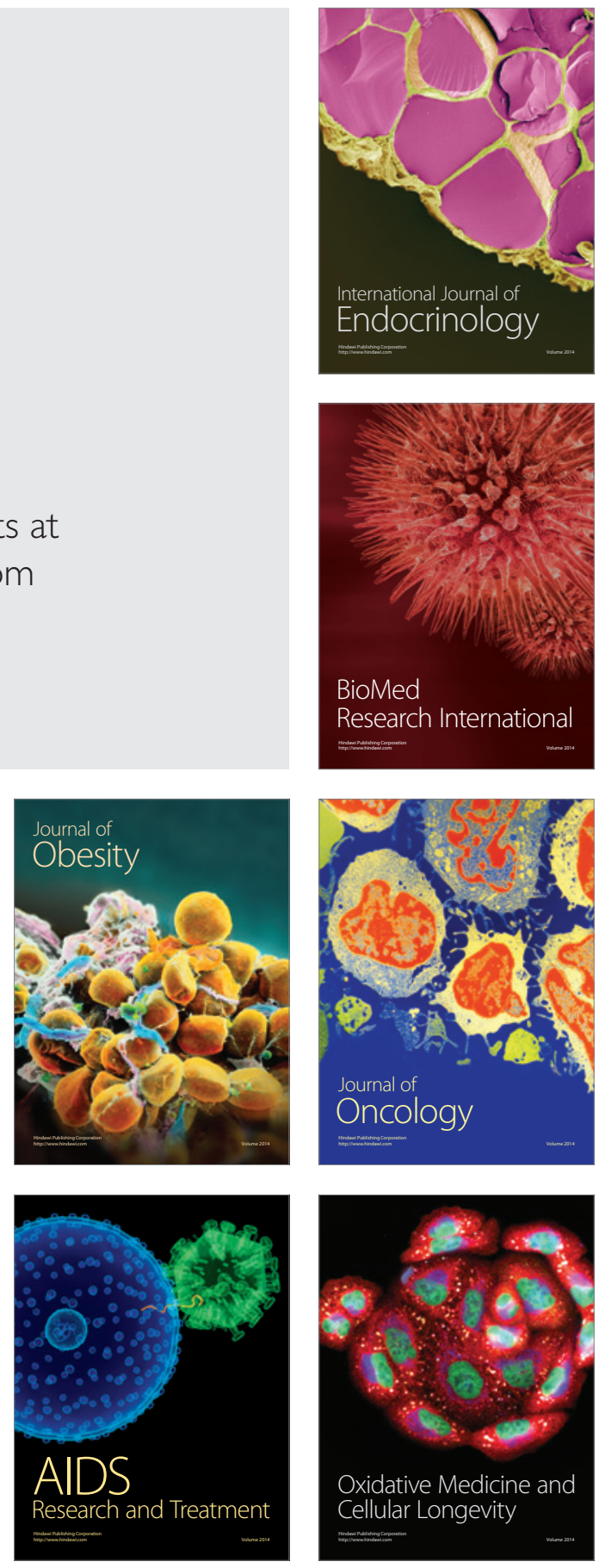